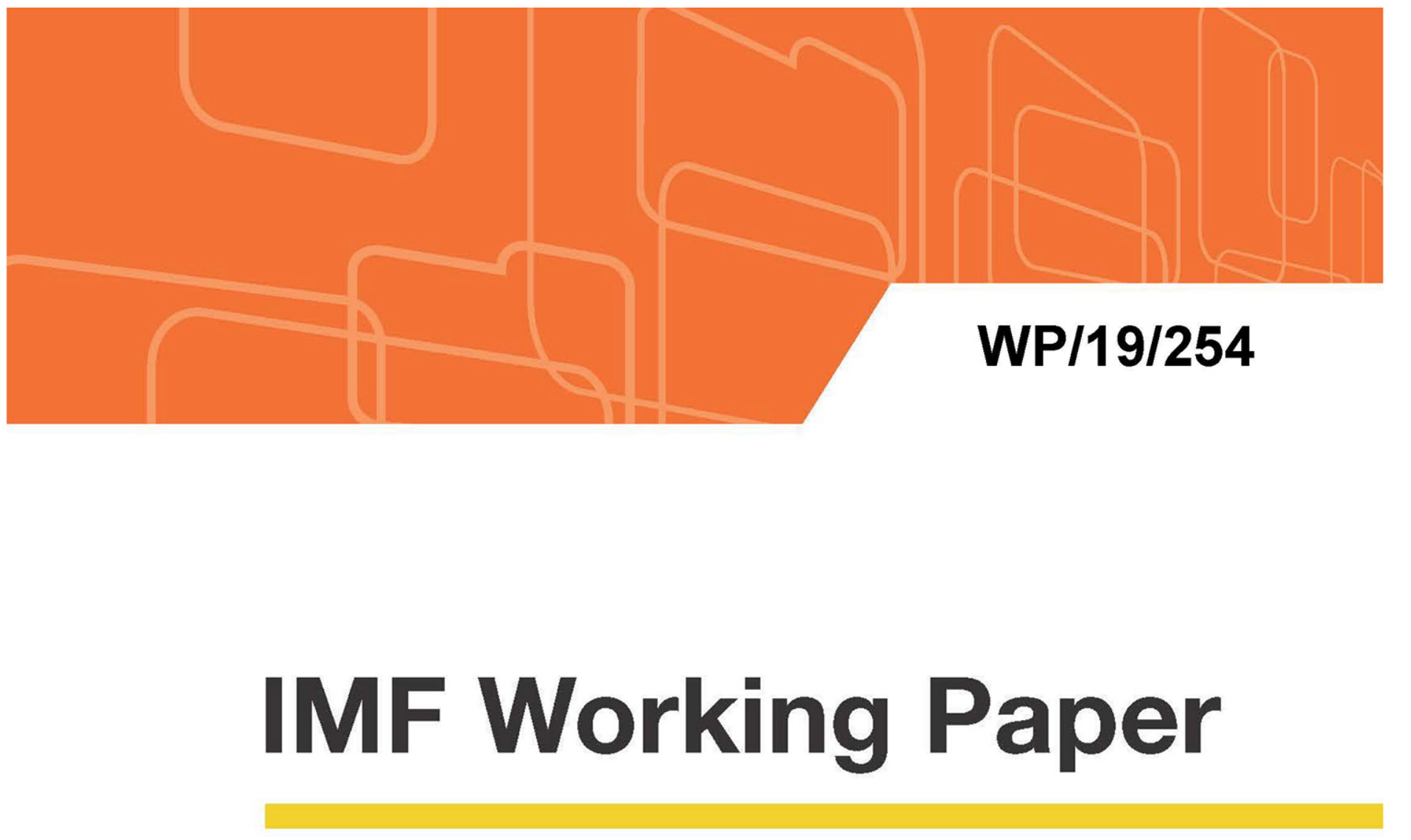

\title{
Breaking the Bank? \\ A Probabilistic Assessment of Euro Area Bank Profitability
}

by Selim Elekdag, Sheheryar Malik, and Srobona Mitra

IMF Working Papers describe research in progress by the author(s) and are published to elicit comments and to encourage debate. The views expressed in IMF Working Papers are those of the author(s) and do not necessarily represent the views of the IMF, its Executive Board, or IMF management. 


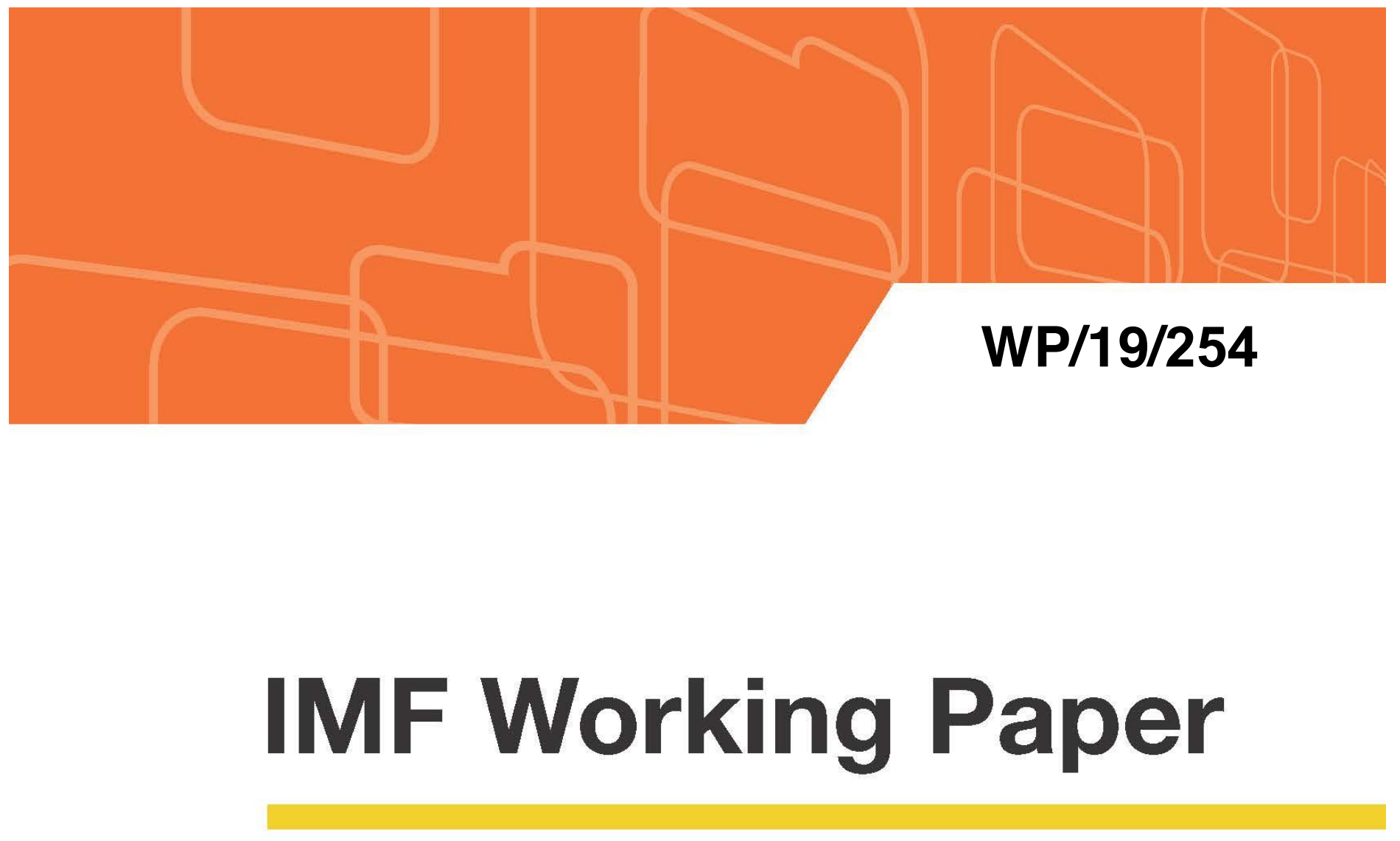

\section{Breaking the Bank? \\ A Probabilistic Assessment of Euro Area Bank Profitability}

by Selim Elekdag, Sheheryar Malik, and Srobona Mitra

IMF Working Papers describe research in progress by the author(s) and are published to elicit comments and to encourage debate. The views expressed in IMF Working Papers are those of the author(s) and do not necessarily represent the views of the IMF, its Executive Board, or IMF management. 


\title{
IMF Working Paper
}

Monetary and Capital Markets Department

\section{Breaking the Bank? A Probabilistic Assessment of Euro Area Bank Profitability}

Prepared by Selim Elekdag, Sheheryar Malik, and Srobona Mitra ${ }^{1}$

Authorized for distribution by Prasad Ananthakrishnan

November 2019

\section{IMF Working Papers describe research in progress by the author(s) and are published to elicit comments and to encourage debate. The views expressed in IMF Working Papers are those of the author(s) and do not necessarily represent the views of the IMF, its Executive Board, or IMF management.}

\begin{abstract}
This paper explores the determinants of profitability across large euro area banks using a novel approach based on conditional profitability distributions. Real GDP growth and the NPL ratio are shown to be the most reliable determinants of bank profitability. However, the estimated conditional distributions reveal that, while higher growth would raise profits on average, a large swath of banks would most likely continue to struggle even amid a strong economic recovery. Therefore, for some banks, a determined reduction in NPLs combined with cost efficiency improvements and customized changes to their business models appears to be the most promising strategy for durably raising profitability.

JEL Classification Numbers: C32, E30, G01, G21

Keywords: Bank profitability, quantile regressions, conditional distributions

Author's E-Mail Address: Selekdag@,imf.org; SMalik@,imf.org; SMitra@,imf.org

\footnotetext{
${ }^{1}$ The views expressed in this working paper are those of the authors and do not necessarily represent the views of the IMF, its Executive Board, or IMF management. The authors would like to thank Daniel Hardy, Hannah Hempell, Deniz Igan, Christopher Kok, James Morsink, Georges Pineau, Lev Ratnovski, Thierry Tressel, and Laura Valderrama for their insightful comments, and Rohit Goel, Elizabeth Mahoney, Jesse Siminitz for excellent research assistance and Kateryna Botsu for excellent editorial assistance.
} 


\section{Contents}

Abstract

I. Introduction $\underline{4}$

II. Conceptual and Empirical Framework 7

A. Conceptual Framework 7

B. Econometric Approach 10

C. Conditional Profitability Distributions 11

III. Data, Key Trends, and Stylized Facts $\underline{12}$

A. Data $\underline{12}$

B. Key Trends and Stylized Facts 13

IV. Econometric Analysis $\underline{15}$

A. Benchmark OLS Regression Analysis___ 15

B. Robustness Analysis

C. Quantile Regression Analysis $\underline{18}$

V. Conditional Profitability Distributions $\underline{18}$

VI. Conclusions and Policy Implications $\underline{21}$

References $\underline{34}$

FIGURES

1. Euro Area Banks (Significant Institutions): Key Trends and Stylized Facts $\underline{31}$

2. Illustrative Conditional Profitability (ROE) Distributions $\underline{32}$

TABLES

1. Euro Area Bank Sample $\underline{22}$

2. Descriptive Statistics of Main Variables 23

3. Stylized Facts: Key Bank-Specific Determinants $\underline{23}$

4. Baseline Profitability Regressions: Return on Assets and Components___ 24

5. Robustness Analysis: Return on Assets $\underline{25}$

6. Return on Equity Regressions $\underline{26}$

7. Robustness Analysis: Risk-Adjusted Profitability Measures $\underline{27}$

8. Quantile Regressions: Return on Assets $\underline{28}$

9. Quantile Regressions: Return on Equity 29

11. Summary: Conditional Profitability (ROE) Distributions $\underline{30}$ 


\section{INTRODUCTION}

European banks' profitability has been low for over a decade, in aggregate and in particular, for a "tail" of weak performers. Although two key headline profitability measures - return on assets (ROA) and return on equity (ROE) - have edged up in 2018, low bank profitability remains a concern for numerous banks across the area. ${ }^{2}$ Specifically, the ROA and ROE of many banks declined substantially after the global financial crisis and have remained at low levels ever since, even after allowing for lower interest rates (Figure 1). Moreover, forecasts by market analysts suggest that many banks' ROE levels will most likely remain below 8 percent in coming years, which would likely continue to act as a drag on bank share prices. ${ }^{3}$

Banks' persistently weak profitability is a systemic financial stability concern in the euro area. Banks may have ample capital to cushion against shocks, but need profits in order to (re-) build buffers by retaining earnings or attracting new capital. In addition, weaker profitability could foster undue risk-taking aimed at generating higher returns (gambling for resurrection), which would heighten systemic risk. ${ }^{4}$ These concerns continue to apply to many European banks.

There is an active debate in both policy circles and academia on the relative importance of different drivers of bank profitability. Most papers acknowledge that profitability is driven by a variety of bank-specific, cyclical, and structural factors. ${ }^{5}$ One side of the debate argues that cyclical factors, including growth, are dominant (see Kok, More, Pancaro, 2015, for European banks; and Albertazzi and Gambacorta, 2009, for a broader set of countries). The other side of the debate acknowledges the role of cyclical conditions, but highlights the importance of structural factors (see, for example, Demirguc-Kunt and Huizinga, 1999;

\footnotetext{
${ }^{2}$ For example, for the largest euro area banks, which are under the direct supervisory purview of the Single Supervisory Mechanism (known as significant institutions, "SIs"), ROE rose from 5.92 percent in 2017 to 6.16 percent in 2018 (see ECB Financial Stability Review, May 2019).

${ }^{3}$ The 8 percent ROE threshold is based on investor surveys suggesting that banks' cost of equity-with all the standard caveats about its measurement-is currently about 8-10 percent (GFSR 2017 and ECB 2019).

${ }^{4}$ Moreover, low profitability may inhibit proactively addressing impaired assets as write-down could further erode earnings. Weak profits could also potentially force banks to reduce assets and thereby hamper credit intermediation to the real economy. On gambling for resurrection and risk-shifting behavior, see GFSR, October 2014, Chapter 3. Likewise, weak profitability increases the cost of raising capital from investors, potentially further undermining earnings.

${ }^{5}$ For selected, relatively recent, examples, see Demirguc-Kunt and Huizinga (2010), Dietrich and Wanzenried (2011), Mirzaei, Moore, and Liu (2013), Shehzad and others (2013), Gambacorta and others (2014) Alessandri and Nelson (2015), Kok, More, and Pancaro (2015), Borio, Gambacorta, Hofmann (2017), and Detragiache, Tressel, and Turk-Ariss (2018).
} 
Dietrich and Wanzenried, 2011; IMF, 2017; and Detragiache, Tressel, and Turk-Ariss, 2018; IMF 2018). ${ }^{6}$

Much of the related literature focuses on average profitability dynamics across banking systems. Even when using a panel of diverse banks, these papers report how selected determinants affect bank profitability on average. Yet, this practice could misinform policymakers, especially when considering a very heterogeneous banking system such as that in the euro area. For instance, although the average profitability across banks would most likely increase amid an economic upswing, this increase in profitability may be predominantly driven by banks with sound balance sheets. In contrast, a large share of banks with weaker balance sheets may not be in a position to benefit from stronger economic growth. Therefore, focusing only on the soundness of banks on average would mask the deeper structural problems concentrated in the weaker tail of the bank profitability distribution.

To fill this gap in the literature, this paper proposes a probabilistic approach, which places greater emphasis on bank heterogeneity by focusing on bank profitability distributions. Accordingly, the paper is structured around several related questions: What are the key bankspecific, cyclical, and structural determinants of bank profitability? How would a change in these determinants affect the conditional distribution of banks' profitability? More specifically, how would higher growth, or, for example, a lower nonperforming loan (NPL) ratio, affect the profitability distribution, particularly the lower tail of the distribution?

Focusing on large euro area banks, this paper addresses these questions with a relatively novel approach:

- First, to lay the ground work, and facilitate comparability with the literature, panel regression analysis is used to establish the most reliable determinants of bank profitability. The analysis focuses on the profitability of the largest euro area banks ("significant institutions", SIs) which are under the supervisory perimeter of the Single Supervisory Mechanism (SSM).

- Second, in the more novel part of the paper, quantile regressions are used to generate profitability distributions conditional on bank-specific, cyclical, and structural determinants. Selected determinants are then shocked to assess how the shape of the profitability distribution for a "representative" bank changes - an approach which goes beyond standard comparative statics centered on averages. Importantly, this innovative method can be used to quantify how selected determinants influence the probability of banks' profitability being above or below a certain threshold deemed important for

\footnotetext{
${ }^{6}$ Moreover, there is a vast literature on the role of market structure and banking-system concentration that can be traced back to at least the work of Short (1979) which is briefly reviewed below. More recent studies also emphasize other cyclical determinants of bank profitability including financial and monetary conditions (Detragiache, Tressel, and Turk-Ariss, 2018; Borio, Gambacorta, Hofmann, 2017).
} 
market analysts or policymakers. Specifically, comparative static exercises are conducted to quantify the likelihood of ROE remaining below 8 percent in response to changes to higher GDP growth, or lower NPL ratios.

The main results of the paper can be summarized as follows:

- The most robust determinants of bank profitability across large euro area banks appears to be real GDP growth and the NPL ratio. An increase in the growth rate of 1 percentage point is associated with a 15-35 basis point rise in ROA, which is considerable given that average ROA across banks over 2007-2016 was 34 basis points. There is some evidence suggesting that growth boosts bank profits mainly by reducing loan loss provisions and enhancing noninterest income. A 1 percentage point decline in the NPL ratio can lift ROA by about 4-9 basis points. ${ }^{7}$ Findings suggest that a higher stock of NPLs is associated with higher servicing costs tied to impaired loans, which represent an additional drag on bank profitability.

- Although higher growth would lift profitability on average, it may not affect all banks to the same degree. This is evidenced by illustrative conditional profitability distributions estimated for the 109 SIs in the sample over 2007-2016. Estimates suggest that, under the baseline, the likelihood of a (representative) bank's ROE falling below 8 percent remains elevated at 83 percent, ceteris paribus. A hypothetical scenario indicates that raising growth by 1 standard deviation (that is, 3.3 percentage points) reduces this likelihood by 21 percentage points. However, even though average bank profitability increases, the probability of ROE coming in below 8 percent is still substantial.

- However, under a scenario with higher growth and a lower NPL ratio, the probability of a representative bank having an ROE less than 8 percent now declines to 49 percent, a difference of 33 percentage points relative to the baseline. Importantly, the joint materialization of higher growth and lower NPLs reduces the probability of ROE falling below 8 percent more than these shocks considered individually (reflecting nonlinear interactions). This scenario could be interpreted as demonstrating the benefits of an aggressive NPL reduction in the context of a robust economic upswing.

- Additional results suggest that lower cost-to-income ratios are associated with higher profitability for banks outside of the weakest end of the profitability spectrum, but the results on business models and market concentration are more mixed. Moreover, it is difficult to identify whether higher short-term interest rates and a steeper yield curve would generally raise ROA or ROE; there are counterbalancing effects which may differ across banks depending on their business models.

\footnotetext{
${ }^{7}$ The semi-elasticity on the NPL ratio is smaller than that on GDP growth, but NPL ratios are much higher and more variable than GDP growth rates. Over the sample period, European growth rate and the NPL ratio averaged 0.8 percent and 7.4 percent, respectively.
} 
A key takeaway is that an economic recovery alone will likely be insufficient to resolve many banks' enduring profitability challenges. For some banks in particular, a determined reduction in NPLs, combined with improvements in cost efficiency, holds the most promise in durably raising profitability. Such a strategy stands to also benefit from a customized approach to revising individual bank business models.

\section{CONCEPTUAL AND EMPIRICAL FRAMEWORK}

This section begins with a selected review of the literature on the determinants of bank profitability and provides an overview of the econometric framework. It then discusses the generation of bank profitability distributions conditional on selected determinants.

\section{A. Conceptual Framework}

The theoretical and empirical literature has proposed several determinants of bank profitability, which can be grouped into three broad categories: (1) bank-specific, (2) cyclical, and (3) structural. Key determinants, the rationale for their inclusion, and previous empirical results on their relevance are discussed in this section. In many cases, the theoretical impact of these determinants on profitability remains inconclusive, which further motivates our empirical investigation.

\section{Bank-Specific Determinants}

Bank-specific determinants of profitability can be split into two broad categories. The first encompasses financial soundness indicators such as solvency and asset quality, while the second category covers measures of size, efficiency, diversification, and business models. The set of bank-specific determinants are generally similar across many empirical studies and are summarized below.

- Solvency: Although bank capital is considered an important determinant of profitability, its impact is ambiguous. Banks with higher capitalization ratios tend to face lower funding costs owing to lower bankruptcy costs, thus supporting earnings (Demirguc-Kunt and Huizinga, 1999; and Detragiache, Tressel, and Turk-Ariss, 2018). In contrast, greater capital ratios may be associated with lower risk-taking and thereby lower expected returns (Goddard and others, 2004). Likewise, as banks get closer to default (when capital is nearly depleted), shareholders and managers have less to lose from failure (and more to gain from success), and so may be willing to take excessive risks with the hope that greater earning will restore solvency ("gambling for resurrection"- -see Akerlof and Romer, 1993; Hellmann, Murdock, and Stiglitz, 2000; Freixas, Parigi, and Rochet, 2004, and GFSR 2014, October, Chapter 3). ${ }^{8}$

\footnotetext{
${ }^{8}$ Such a hypothetical situation is likely to be associated with insufficient governance and risk management frameworks. Likewise, risk-taking behavior is likely to be influenced by the macroeconomic environment, whereby banks' risk tolerance may increase or lending standards may decrease during booms for example.
}

(continued...) 
- Asset quality: NPLs - a standard measure of asset quality — are used as a risk management metric, and the level of risk is a key factor driving banks' overall performance. Greater risk and returns tend to go hand in hand, at least in the near term. However, banks which take on greater risks tend to eventually incur higher losses, which reduce returns. Empirical evidence suggests that higher credit risk (proxied with NPL or provisioning ratios) is characterized by lower profitability (Bikker and $\mathrm{Hu}, 2002$; Altavilla, Boucinha, and Pedyro, 2018; and Detragiache, Tressel, and Turk-Ariss, 2018). For instance, elevated stocks of NPLs can be problematic because they create uncertainty regarding the quality and valuation of assets, thereby potentially rendering funding more expensive, among other things. In addition, NPLs can act as a drag on earnings by increasing operational and legal costs. ${ }^{9}$

- Size: Controlling for bank size is important, but its relation to profitability is not conclusive (Shehzad and others, 2013). Some studies argue that larger banks benefit from economies of scale, thereby enhancing the bottom line (Berger, 1995; and Goddard, Molyneux, and Wilson, 2004). In contrast, other studies claim that larger banks suffer from diseconomies to scale reflecting agency, overhead, and managerial costs (Tregenna, 2009).

- Efficiency: Better operating efficiency is typically associated with greater bank profitability (Molyneux and Thornton, 1992; Dietrich and Wanzenried, 2011; and Detragiache, Tressel, and Turk-Ariss, 2018). Standard measures include cost-to-income or cost-to-assets ratios, occasionally differentiating between personnel and non-personnel costs (Demirguc-Kunt and Huizinga, 2010).

- Diversification: The link between more diverse revenue streams and profitability is also contested. Some studies claim that there is a positive relationship (Valverde and Fernandez, 2007; and Demirguc-Kunt and Huizinga, 2010), but perhaps to a certain degree (Gambacorta and others, 2014), while others find a negative link as a higher share

Laeven and Levine, 2009, emphasize the importance of bank risk taking and corporate governance structures. Berger and Bouwman, 2013, who document that greater capital help bank increase their probability of survival and market share. Beltratti and Stulz, 2012, show that banks with more capital performed better during the global financial crisis.

${ }^{9}$ In particular, NPLs need to be handled by potentially sizable teams of specialized staff and the workout process can be timely. In addition, NPLs do not generate interest income, and owing to higher risk weights, they can hold back lending (for further details, see, for example, Baudina and Yun, 2017). Note also that NPL reduction would entail capital costs when the price of such NPLs is below book value or if NPLs have to be written off (against capital). At the same time, total assets would also fall if NPLs are written off. Given that it is a priori unclear how such changes to the NPL ratio would affect bank capital (equity-to-assets ratio), the regressions include the equity-to-assets ratio. See also Xu, Hu, and Das (2019) and Altunbas, Manganelli, and Marquez-Ibanez (2011). 
of non-interest income is associated with more volatile earnings (Stiroh, 2004; and Kok, Mirza, More, and Pancaro, 2016).

- Business models: It is also important to consider banks' diverse business models (Valverde and Fernandez, 2007; Demirguc-Kunt and Huizinga, 2010; Kok, More, and Petrescu, 2016; and Detragiache, Tressel, and Turk-Ariss, 2018). While several studies have proposed business model classifications, such characterizations have overlapping features that are sometimes difficult to correlate with profitability (Ayadi and others, 2015; BIS, 2017; GFSR 2017). Therefore, as a first pass, the deposit-to-asset and loan-toasset ratios are used as two broad indicators of balance sheet characteristics of banks that describe the thrust of their business models. ${ }^{10}$

\section{Cyclical Determinants}

Accounting for the macroeconomic environment is standard practice, and many studies find that profitability is procyclical (for example, Albertazzi and Gambacorta, 2009). An economic expansion will increase the demand for intermediation services (including lending and underwriting and advisory services) thereby lifting net interest income, fees, and commissions. In addition, improving asset quality will reduce the need for loan loss provisioning and thus contribute to profitability.

Other cyclical factors can also influence banks' profitability. For instance, many of the aforementioned studies control for (short-term) policy rates, longer-term interest rates, or the slope of the yield curve. Although conventional wisdom suggests that a steeper yield curve would boost profitability by improving bank income margins, higher long-term interest rates can also reduce the valuation of longer-term securities (Alessandri and Nelson, 2015; Borio, Gambacorta, and Hofmann, 2017). The impact of short-term interest rates on profitability is even more ambiguous given the differing presence of loan-pricing frictions across banks. The impact on bank profits is estimated to be positive in Demirguc-Kunt and Huizinga (1999), negative by Alessandri and Nelson (2015), and insignificant by Albertazzi and Gambacorta (2009). More recently, Altavilla, Boucinha, and Pedyro (2018) argue that monetary easing (a decrease in the short-term interest rate and/or a flattening of the yield curve) is not associated with lower bank profits.

Given the turbulent market conditions witnessed over the past decade, it is important to control for financial conditions more broadly. To this end, a new euro area financial conditions index (FCI) was used, which includes measures of spreads and volatility which tend to spike during episodes of acute market distress (for details, see Arregui and others, 2018). As emphasized in Adrian, Boyarchenko, Giannone (2019), tighter FCI outturns are

\footnotetext{
${ }^{10}$ Both in the context of revenue diversification and as a business model indicator, the trading assets-to-total assets ratio was considered, but not included because of a dearth of data.
} 
associated with a higher likelihood of future recessions. Another benefit of including FCIs is that they include real estate prices, which may be particularly relevant given the role of real estate as collateral. Country-specific versions of the FCI were used. In addition, an aggregate euro area FCI was considered (but not shown for sake of brevity). ${ }^{11}$

It is also important to account for major crisis periods to ensure such shocks are not driving the results. Hence, in the baseline and most other specifications, time fixed effects are included to capture regional and global developments that may affect banks' profitability.

\section{Structural and Other Determinants}

Investigating the role of market structure can be traced back to at least the work of Short (1979). Market concentration measures are one of most commonly used structural determinants of bank profitability. Opposing hypotheses consider whether concentration results in collusion or greater competition with attendant implications on bank revenues. ${ }^{12}$ Other potential structural determinants including ownership, governance, and supervisory regimes could also affects banks performance, however, because of data limitations, they are not considered in this study. ${ }^{13}$

\section{B. Econometric Approach}

To set the stage, and to facilitate comparability with other studies, the empirical approach begins with standard panel regression analysis. An abridged representation of the baseline specification is as follows:

$$
y_{b, c, t}=\alpha * X_{b, c, t-1}+\beta * Z_{c, t}+\gamma * W_{c, t}+\text { Other }_{b, c, t}
$$

\footnotetext{
${ }^{11}$ Note also that Detragiache and others (2018) investigate profitability over the financial cycle.

${ }^{12}$ See for example Bourke (1989), Molyneux and Thornton (1992), Berger (1995), Berger and others (2000), Trigenna (2009), and Mirzaei, Moore, and Liu (2013), In the presence of scale and scope economies, rising bank concentration may reduce borrowing costs. However, if accompanied by rising market power, greater concentration may under some conditions lead to higher spreads and suboptimal credit volumes. Erel (2011), for example, finds that rising bank concentration increases the cost of financial intermediation. The market concentration measure along with the cost-to-income ratio should capture the implications of (excessive) branch network size and headcounts as well as the lack of sufficient IT investment needed to reap the benefits of greater digitization. Note that impact of size and concentration on profitability are related.

${ }^{13}$ For example, even the updated supervisory indicators by Barth and others (2006) end in 2011. Likewise, more recent studies such as Barth and others (2013) use data up to 2007. Data coverage also limits the inclusion of indicators that could capture quasi-public competitors (including in some cases, cooperatives) and nonbank competition. Iannotta, Nocera, and Sironi (2007) as well as Micco, Panizza, and Yanez (2007) find that government-owned banks exhibit lower profitability relative to privately-owned banks. The governance indicators used by Laeven and Levine (2009) are only available for a single year. Demirguc-Kunt and Huizinga (1999) also consider the role of the strength of institutions (using, for example, proxies such as law and order indices).
} 
where $y_{b, c, t}$ denotes the headline profitability measures (ROA, ROE) and relevant income components (for example, net interest income and non-interest income) for bank $b$, in country $c$, in year $t$; the vectors $X_{b, c, t-1}, Z_{c, t}$, and $W_{c, t}$ encompass the bank-specific, cyclical, and structural determinants; Other $_{b, c, t}$ includes (bank and time) fixed effects terms and a residual term. Building on this baseline specification, an array of robustness checks are conducted. More importantly, this specification forms the basis of the quantile regressions used to generate conditional profitability distributions.

\section{Conditional Profitability Distributions}

The most novel aspect of this paper is the estimation of conditional bank profitability distributions. In particular, quantile regressions are used to generate profitability distributions conditional on the bank-specific, cyclical, and structural determinants reviewed above. Selected determinants can then be shocked to assess how the shape of the profitability distribution changes - an approach which clearly goes beyond standard comparative statics centered on averages. Importantly, this powerful method can be used to quantify how selected determinants influence the probability of banks' profitability being above and below a certain threshold of interest.

The link between profitability and the underlying determinants can be made using quantile regressions. Consider the following simplified specification:

$$
y_{b, c, t}^{q}=\beta^{q} \Xi_{b, c, t}+\epsilon_{t}^{q}
$$

where $y_{b, c, t}^{q}, \Xi_{b, c, t}, \epsilon_{t}^{q}$, and $q$ denote the measure of profitability; the set of (bank-specific, cyclical, and structural) determinants; a residual term (as well as bank and time fixed effects terms); and various percentiles of interest, for example, $q=\{0.05 ; 0.25 ; 0.50 ; 0.75 ; 0.95\}$, respectively. ${ }^{14}$ The estimated conditional quantile function (inverse cumulative distribution function) would in turn correspond to $\hat{y}_{b, c, t}^{q}\left(=\hat{\beta}^{q} \Xi_{b, c, t}\right)$, which is used to generate the conditional profitability distributions.

The conditional distribution is estimated by fitting a flexible parametric distribution to the data. Given the noisiness of quantile functions estimates in practice, recovering the corresponding probability density function (PDF) will require smoothing of the quantile function. In line with the approach of Adrian, Boyarchenko, and Giannone (2019), this is accomplished via fitting a (parametric form) 'skewed' $t$-distribution: ${ }^{15}$

\footnotetext{
${ }^{14}$ On quantile regress analysis, see Koenker and Bassett (1978) and Koenker (2005).

${ }^{15}$ See also, GFSR April 2017 Chapter 2, and GFSR October 2017 Chapter 3.
} 


$$
f(y ; \mu, s, v, \xi)=\begin{array}{ll}
\frac{2}{\xi+\frac{1}{\xi}} g(z) \xi, & z<0 \\
\frac{2}{\xi+\frac{1}{\xi}} g(z) / \xi, & z \geq 0
\end{array}
$$

where $g(z)=\bar{g}(z ; v) / s$, with $\bar{g}($.$) denoting the PDF of standard Student- t$ with $v$ degrees of freedom; $z$ is given by $((y-\mu) / s)$, with $\mu$ and $s$ referring to location and scale parameters, respectively. Skewness is governed by shape parameter $\xi$. This functional form for the skewed $t$-distribution is based on that motivated by Fernandez and Steel (1998), further explored and refined in Giot and Laurent (2003) and Lambert and Laurent (2002); see also Boudt, Peterson and Croux (2009). ${ }^{16}$ For specified values for the conditioning variables, the four parameters $\{\mu, s, v, \xi\}$ of the implied density are pinned down by minimizing the squared distance between the estimated quantile function, $\hat{y}^{q}$, and theoretical quantile function $y^{q, f}(\mu, s, v, \xi)$ corresponding to the above skewed- $t$ distribution. Specifically, the $5^{\text {th }}, 25^{\text {th }}, 50^{\text {th }}, 75^{\text {th }}$ and $95^{\text {th }}$ percentiles, for example, can be matched via distance minimization:

$$
\{\mu, s, v, \xi\}=\underset{\mu, s, v, \xi}{\operatorname{argmin}} \sum_{q}\left\{\hat{y}^{q}-y^{q, f}(\mu, s, v, \xi)\right\}^{2}
$$

where $\mu \in \mathbb{R}, s>0, v \geq 2$ and $\xi>0$. Notwithstanding the skewness property, the choice of a skewed- $t$ functional form is advantageous from the perspective of flexibility. For example, as $v \rightarrow \infty, f(y ; \mu, s, v, \xi)$ is characterized by tail properties resembling a Gaussian; moreover, the density is symmetric when $\xi=1$.

\section{DATA, KeY TRENDS, AND STYLIZEd FACTS}

Before proceeding to the econometric analysis, this section provides an overview of the data and presents some key stylized facts.

\section{A. Data}

Data on large euro area banks is collected from publicly available sources. Balance sheet and income statement information from the FitchConnect database over 2007-2016 are complemented with country-level macroeconomic data and various structural indicators. Following the approach adopted by the European Banking Authority and the ECB, bank statements at the highest level of consolidation were used. The 109 SSM-supervised banks

\footnotetext{
${ }^{16}$ Alternative specifications for the skewed $t$-distribution are present in literature, for example, as put forth by, among others, Hansen (1994) and Azzalini and Capitanio (2003). These are essentially equivalent given a (nonlinear) transformation of the skewness parameter.
} 
amounted to about $€ 23$ trillion in total assets in 2015 , the year with the largest number of banks in the sample (Table 1). ${ }^{17}$

It is important to recognize several features of the data which can affect the results. First, some indicators may change over time because of merger and acquisition activity. Second, banks that closed during the sample period were excluded, creating survivorship bias. Third, some banks have sizeable international operation and are thus influenced by global macroeconomic conditions. Fourth, included in the list of significant institutions are those that are more like development banks and do not engage in traditional lending and trading activities.

Some of these potential concerns are addressed as follows: First, as discussed below, both bank and time fixed effects terms are included in the baseline regressions. The former accounts for time-invariant bank-specific features and the latter captures regional and global developments that may be important with banks with significant exposures beyond the euro area (and also captures turbulent market conditions). Second, as a robustness check, the regressions are re-estimated using a balanced sample of banks. Third, quantile regressionswhich are less sensitive to outliers - are undertaken for comparison. The baseline specifications are also complemented by an array of robustness checks.

\section{B. Key Trends and Stylized Facts}

Average profitability has been on a downtrend since 2007, but there is wide variation among banks:

- To assess key trends more accurately, a balanced sample of 45 SSM-supervised significant institutions (SSM SIs), accounting for 56 percent of sample assets in 2016, is used. Figure 1 displays the median, $25^{\text {th }}$ and $75^{\text {th }}$ percentiles, as well as the weighted average for a few bank-specific variables in this sample over 2007-2016. The two headline measures of profitability, ROA and ROE, have been persistently low over the past decade, but with notable variation across banks. Moreover, banks' average ROE continues to trail market estimates of the cost of equity, and analysts do not expect this situation to change quickly for many banks despite the ongoing recovery. It is also important to recognize recent progress: ROE in 2017Q4 was about 6 percent on average across all SIs.

- Table 2 summarizes some stylized facts that reinforce the concerns associated with euro area bank's profitability. The ROA outturn for 2016, at 0.34 percent, is the same as the sample average, and has a sizeable standard deviation. Despite a higher reading relative to the 2007-2016 period, average ROE stood at only 4.1 percent in 2016 . The starker

\footnotetext{
${ }^{17}$ Note that the assets of euro area banking system was about $€ 25$ trillion at end-2017 based on consolidated banking data.
} 
variation across banks partly reflects the fact that small difference in leverage (the inverse of Equity/Assets) could make a significant difference in ROE.

Low profitability is pervasive across bank business models. A scatterplot of SSM banks against two indicators - loans-to-assets and deposits-to-assets - enables us to see the distribution of SSM assets by broad business models (Figure 1). Although this twodimensional business model classification is simplistic and based on coarse proxies, it nevertheless highlights the diversity of the largest euro area banks. Banks in the northeast corner are designated as "traditional" banks with an above-median share of loans-to-assets and deposits-to-assets and comprise $€ 4$ trillion in assets. On the other extreme are the "nontraditional" banks that have a large share of trading assets and depend more on wholesale funding. This set of banks includes the euro area global systemically important banks (G-SIBs) and accounts for $€ 14$ trillion in assets. Many banks are scattered across these two polar cases. The red dots indicate banks with ROE less than 8 percent, the lower range of the minimum cost-of-equity desired by investors - the incident of low ROE is strewn across a wide variation in business models.

NPL and cost-to-income ratios also display significant dispersion across banks. A fallout of the crises in the euro area has been high nonperforming loans across banks (as a share of gross loans, that is, the NPLs ratio), which is coming down gradually, but progress remain uneven (Figure 1). The average NPL ratio remained elevated in 2016, albeit concentrated in some banks, as reflected in the large standard deviation (Table 2). Overhead (non-interest) costs, as a share of operating income, is higher in 2016 than the sample average, likely reflecting the inertia of expenses related to large branch networks and servicing of nonperforming loans for traditional banks, and fees and fines for others. Other key bankspecific characteristics vary notably across banks as well.

Average GDP growth, which included both the crisis and the recovery, is below the current estimates of potential growth. Over the 2007-2016 sample that is considered in the analysis, average real GDP growth was 0.8 percent, with wide cross-country differences due to both the global financial crisis and the European debt crisis (the standard deviation of growth was 3.3 percent as shown in Table 2). In 2016, growth rate rose to 1.2 percent and its standard deviation declined. This observation is in line with the synchronized nature of the recovery of the euro area countries, with all countries growing, and the variation in growth among countries at the lowest since the advent of the euro. Nevertheless, and at the time of writing, conjunctural projections have deteriorated again.

Slicing through the ROE distribution reveals monotonic trends associated with the NPL and cost-to-income ratios. Table 3 shows the main bank-specific characteristics across four ROE levels in 2016: below the $25^{\text {th }}$ percentile $(<\mathrm{Q} 1)$, between $25^{\text {th }}$ and $50^{\text {th }}$ percentile $(\mathrm{Q} 1-\mathrm{Q} 2)$, between $50^{\text {th }}$ and $75^{\text {th }}(\mathrm{Q} 2-\mathrm{Q} 3)$, and above $75^{\text {th }}$ percentile $(>\mathrm{Q} 3)$. The skewed nature of the ROE distribution is noticeable: the ROE of banks in the left tail have an average of -16 percent, 20 percentage points worse than that of the next quartile; ROE in the top quartile is only about 5 percentage points higher than in the second highest. Banks in left end of the 
distribution have an ROA of -1 percent, an NPL ratio of 22 percent, and a cost-to-income ratio of 81 percent on average. These banks seem to confront similar challenges, but to varying degrees, which tend to be distinct from the other SIs in the sample. Specifically, moving rightwards across the columns uncovers a monotonic decrease in both cost-toincome and NPL ratios.

\section{ECONOMETRIC ANALYSIS}

The section presents the OLS and quantile regression results as well as discusses robustness.

\section{A. Benchmark OLS Regression Analysis}

The baseline results show that real GDP growth and the NPL ratio, besides total assets, are the most reliable determinants of bank return on assets. Table 4 shows the baseline ROA specification under the first column, as well as key ROA components and other dependent variables to shed further light on the main channels driving the results. Other than size, real GDP growth and the NPL ratio appear to be the two statistically significant determinants of ROA. A 1 percentage point increase in growth would raise ROA by 27 basis points. Given that average ROA across banks over 2007-2016 was 34 basis points, this is a notable increase. The results also indicate that the marginal effect of a 1 percentage point lower NPL ratio is a rise in ROA by 5 basis points. Note that over the sample period, growth and the NPL ratio had an average of 0.8 percent and 7.4 percent, respectively. On average, the link between ROA and cost-to-income, concentration, and business model indicators are estimated less precisely. In the case of business models in particular, these mixed results could reflect the coarse nature of the available proxies. Although differences in sample, specifications, and econometric methodology, render comparisons difficult, overall, these findings are broadly similar to those of the studies discussed above.

The components of ROA were then used as dependent variables to explore the channels at play. Specifically, we consider the roles of net interest income, noninterest income, and loan loss provisions (all scaled by assets to facilitate comparability to ROA). ${ }^{18}$ Higher growth results in a rise in noninterest revenue streams (Table 4) and a decline in loan-loss provisioning (column 4), results which are consistent with Altavilla, Boucinha, and Pedro (2018). The negative correlation between loan loss provisions and growth is in line with Huizinga and Laeven (2019). This suggests that the procyclicality of ROA is driven primarily a greater demand for financial services (resulting in higher fees and commissions) and enhanced asset quality during on upswing. Lower NPL ratios would reduce provisioning costs and, hence, increase ROA. Note also that 60 percent of the effect of lagged NPLs on

\footnotetext{
${ }^{18}$ Recall that ROA is calculated by dividing net income (before extraordinary items and taxes) by the (average) value of total assets (financial and nonfinancial over the same period). In turn, net income (before extraordinary items and taxes) can be defined as net interest income (NII) plus net non-interest income minus loan loss provisions minus operating costs (where NII $=$ Interest income - Interest expense and Net non-interest income $=$ Trading income + Fees and commissions + Other operating income). Operating costs include branch and personnel costs.
} 
ROA stem from the provisioning needs (based on columns 1 and 4). Table 4 also includes regressions where the costs-to-assets ratio and pre-provision ROA are dependent variables (shown in columns 5 and 6 , respectively). These supplementary regressions provide evidence suggesting that elevated NPL stocks are associated with costs other than those directly related to provisioning (such as operational and legal expenses). Indeed, a higher NPL ratio is characterized by lower pre-provision ROA.

\section{B. Robustness Analysis}

Growth and NPLs remain significant determinants of profitability even as other variables are included in the baseline specification (Table 5). Various additional variables are added to the baseline ROA to assess the robustness of the main results. Bank-, country-, and regionspecific variables groups are considered. For the first group, bank-specific loan growth and the change in the NPL ratio are considered. The second group includes country-specific measures of the slope of the yield curve (the difference between the 5-year and 3-month government bond yields) and FCIs. The FCI measures the ease of obtaining financing relative to each country's history, see Arregui and others (2018) for further details. The third group includes a single variable, namely the area-wide level of the short-term interest rate (the ECB estimate of the 3-month zero-coupon yield on AAA securities). The baseline specification is also re-estimated using a balance sample as well as with the general method of moments (GMM).

The change in the NPL ratio is a significant determinant but strongly correlated with GDP growth. When added, the change in the NPL ratio is statistically significant and has the expected sign. Therefore, both the stock and the flow of NPLs act as a drag on profitability owing to servicing costs, loan loss provisions, and the likely reduced availability of funds to lend. Since the GDP growth term is included and attention focuses on medium-term effects, the NPL flow term is not included in further analysis.

A steeper yield curve or higher short-term interest rates do not appear to help profitability of these banks on average, which are in line with the findings of Altavilla, Boucinha, and Pedro (2018). The slope of the yield curve is an indicator of the intermediation margin given by the spread between lending and funding rates. All else equal, a steeper yield curve would raise net interest income. However, higher long-term interest rates would reduce the valuations of longer-term securities (that are held in the available-for-sale portfolio for instance). Since the crisis, the maturity of such securities held by banks have gone up, and so the valuation effects are sizeable even as net interest income improves with higher long-term interest rates. ${ }^{19}$ Furthermore, higher interest rates could push highly indebted bank borrowers to default on their loan payments that would increase provisioning costs and decrease profitability.

\footnotetext{
${ }^{19}$ Likewise, Tan (2019) suggests that net interest margins are overall unaffected when policy rates are negative because the volume effect (of greater lending) is large enough to offset the adverse impact on bank profitability (but cautions that the positive on lending dissipates as negative rates persist).
} 
Likewise, bank profitability and short-term interest rates are positively correlated, but this correlation is not statistically significant in this sample. ${ }^{20}$ For related findings, see Alessandri and Nelson (2015).

Tighter financial conditions tend to adversely affect bank earnings. Recall that the FCI discussed above contains various spreads and can therefore affect bank profitability in at least two ways: First, a spike in spreads would result in valuations losses (on holdings of both corporate and government securities). Second, funding costs are likely to rise faster than lending rates, thereby compressing interest margins.

Including a lagged dependent variable or using a balanced sample highlight the robustness of the main findings. Following Kok, More, Pancaro (2015), a lagged dependent variable is included in the baseline and the model is estimated using the GMM estimator developed by Arellano and Bond (1991). There are two main takeaways from these results: First, the lagged dependent variable is statistically insignificant (Table 5). It also has a negative coefficient, perhaps a reflection of large yearly fluctuations in profitability possibly owing to the crisis experiences. Second, the GMM results are consistent with the baseline specification. For example, both the "short-run" coefficients and their "long-run" counterparts are broadly in line with those in the other specifications. Note also that reestimation using a balanced sample produces results very similar to the baseline specification.

Using ROE yields broadly similar findings. The regressions discussed above were estimated using ROE as the main profitability indicator and again indicate the growth and the NPL ratio are the robust determinants (Table 6). Although total assets cease to be a significant determinant, the change in the NPL ratio gains in significance. As will be discussed below, the OLS regressions may mask underlying non-linear relationships, which motivates the use of quantile regression analysis.

A final robustness check considered risk-adjusted profitability metrics. Following DemirgucKunt and Huizinga (2010), the z-score (also interpreted as a measure of bank risk) is considered. The z-score reflects the number of standard deviations that a bank's rate of ROA must fall for the bank to become insolvent. It is constructed as the sum of the mean rates of ROA and the equity-to-assets ratio divided by the standard deviation of ROA (Roy, 1952). A higher z-score signals a lower probability of bank insolvency. In addition, risk-adjusted variants of ROA and ROE are considered whereby each profitability metric is scaled by its respective standard deviation (broadly analogous to a Sharpe ratio). The entire 2007-2016 sample was used to calculate the needed standard deviations as accurately as possible. This

\footnotetext{
${ }^{20}$ When assessing the impact of low interest rates on banks' net interest margins (NIMs), it is important to distinguish between banks granting loans at floating versus fixed rates. The level of short-term interest rates is more important for NIMs of banks with predominantly floating-rate loans, while the slope of the yield curve plays a relatively greater role for banks with a larger share of fixed-rate loans. Furthermore, interest rate effects will differ across business models; the sample excludes smaller, purely retail-oriented banks.
} 
transforms the panel data set into a cross-section (thereby losing many degrees of freedom in the time dimension). Regressions using the full set of banks and the balanced set of banks are shown in Table 7. Note that the NPL ratio is highly statistically significant, whereas the correlation between growth and risk-adjusted profits is less precisely estimated in the crosssection.

\section{Quantile Regression Analysis}

Quantile regressions reveal that growth and the NPL ratio remain the most robust determinants of bank profitability. The results for three quantiles $(25,50$, and 75$)$ are reported for ROA and ROE in Table 8 and Table 9, respectively. To facilitate comparisons, the baseline OLS specification is shown in the first column in each table. For both profitability metrics, growth and the NPL ratio have the expected signs and are statistically significant across all quantiles. Notably, the (absolute value of the) coefficients on growth and NPLs decrease monotonically across the $25^{\text {th }}$ to the $75^{\text {th }}$ quantiles in both sets of regressions. For example, in the ROA regressions, the growth coefficient is 0.2 versus 0.09 in the $25^{\text {th }}$ and $75^{\text {th }}$ quantile regressions, respectively. A similar pattern holds in the case of the NPL ratio. These findings suggest that banks with the greater profitability challenges stand to benefit the most from an increase in GDP growth and from lower NPL ratios.

In contrast to the OLS regressions, the quantile regressions suggest that improved operational efficiency is important for bank profitability. The quantile regressions indicate that lower cost-to-income ratios are associated with higher ROA for banks outside of the weakest end of the profitability spectrum. ${ }^{21}$ Changes to business models hold promise as well. Evidence points to a positive correlation between ROA and a greater deposit-to-asset ratio. ${ }^{22}$

\section{Conditional Profitability Distributions}

As the most novel part of this study, this section discusses the conditional profitability distributions and how shocks to the underlying bank-specific determinants alter the shape of these distributions.

\footnotetext{
${ }^{21}$ The lack statistical significance for the $25^{\text {th }}$ percentile likely reflects the considerable heterogeneity of banks even in the weaker tail of the ROA distribution.

${ }^{22}$ Recall the quantile regressions include both bank and time fixed effects terms. In addition, these regressions were estimated using robust standard errors, clustered standard errors (at the country level following Parente, and Santos Silva, 2016), and bootstrapped standard errors. The main findings are robust to these complementary error structure assumptions (for example, growth and NPLs remain statistically robust across quantiles) and, although these tables were suppressed in the interest of brevity, they available upon request. Recall that the quantile regressions include both bank and time fixed effects terms. (to a large extent). Likewise, and more intuitively, our analysis focuses on essentially attempting to understand behavior of the marginal/representative bank.
} 
Quantile regressions are used to generate conditional profitability distributions. The illustrative ROE distributions are conditional on the determinants included in the quantile regressions discussed above (which are evaluated at their respective sample means). ${ }^{23}$ The distribution has a mean of 5 percent, a mode of 9 percent, and a sizeable standard deviation of 20 percent. ${ }^{24}$ The shape of the conditional distribution is particularly noteworthy as it has a long left tail of chronically low-profitability banks (Figure 2) ${ }^{25}$

The shape of the conditional ROE distributions change when the underlying determinants are shocked, revealing insightful patterns. Recall that the two most reliable profitability determinants were growth and NPLs. In what follows, these two determinants are now shocked to assess how these changes affect profitability. Importantly, the analysis goes beyond the impact on average profitability, but rather considers how changes in these determinants influence the entire ROE distribution. For instance, higher growth (a positive one standard deviation increase relative to the sample average) pulls the distribution to the right. Notice that along with a higher mean, the variance seems to have decreased, and the shocked distribution is less leptokurtic. In particular, notice the thinning out of the left tail in contrast to the increase in mass around what appears to be a ROE level of about 12 percent. Interestingly, a lower NPL ratio (a negative one standard deviation decreases relative to the sample average) results in a broadly similar shift to the right as well. However, notice that in both cases, the skewed nature of the shocked distributions is intact: the long-left tail remains, but the area under it accounts for less mass.

The conditional distributions can be used to make quantitative assessments. For illustrative purposes, and motivated by the stylized facts discussed earlier, the probabilities of ROE above and below the 8 percent threshold are now computed. ${ }^{26}$ These probabilities are shown in Table 10 which comprises of two columns (above and below 8 percent ROE, respectively). The first row depicts these probabilities under the baseline distribution, while the next three rows tabulate the probabilities in response to 1 standard deviation shocks: higher growth, a lower NPL ratio, or their combination. Note that these are large shocks: over our 2007-2017 sample, the standard deviations of growth and the NPL ratio were 3.3 percent and 8.9 percent, respectively.

\footnotetext{
${ }^{23}$ Recognizing that the 2007-2016 sample period includes several crisis episodes, the specifications include time fixed effects terms which account for such turbulent periods.

${ }^{24}$ The ROE data was winsorized to facilitate the visual representation of the conditional distributions and do not change the qualitative conclusions. In the end, the tails were winsorized by 7.5 percent, though 5 percent and 2.5 percent winsorization was also considered.

${ }^{25}$ Conditional ROA distributions are available upon request, reveal broadly similar findings. These were omitted for brevity, but also because ROE can be readily compared to market estimates of the cost of equity.

${ }^{26}$ The framework can easily accommodate other thresholds.
} 
These illustrative simulations suggest that the combination of a decisive reduction of NPLs amid a strong recovery could significantly increase banks' profitability prospects:

- Under the baseline distribution, the probably of a "representative" bank in the sample having ROE less than 8 percent is 83 percent; i.e., 83 percent of the distribution is below 8 percent. $^{27}$

- An increase in the growth of one standard deviation reduces the likelihood of ROE being below 8 percent to 61 percent, and correspondingly raises the probability of a bank with ROE greater than 8 percent by 21 percentage points (to 39 percent). Hence, while higher growth would naturally raise banks' profitability prospects, the shock under consideration is large. ${ }^{28}$ Moreover, notwithstanding the finding that average bank profitability increases, even under this higher growth scenario, the odds of a bank's ROE being below 8 percent are still elevated.

- The quantitative effects of a 1 standard deviation decrease in the NPL ratio results in a broadly similar changes to the contours of the profitability distribution (Figure 2). The likelihood of ROE below 8 percent declines to 72 percent under this scenario.

- The implications of a joint shock, whereby growth increases by one standard deviation and the NPL ratio decrease by the same magnitude, are now investigated. ${ }^{29}$ Three distributions are shown: the baseline, the distribution where on growth is shocked, and the distribution where both growth and NPLs are shocked. The distribution reflecting the joint shocks indicates that the probability of a bank with ROE less than 8 percent now declines to 49 percent - a difference relative to the baseline of about 33 percentage points. Importantly, the joint materialization of these two shocks reduces the probability of ROE falling below 8 percent by more than if these shocks considered individually (a reflection of underlying nonlinear interactions). ${ }^{30}$ This scenario could be interpreted as

\footnotetext{
${ }^{27}$ Recall that these distributions are based on all banks over 2007-2016 which includes episodes of turbulent market conditions (another reason why time fixed effect terms were included). Moreover, notwithstanding the pooled nature of the exercise, the parameter estimation does take into account the degree of bank-specific heterogeneity over the cross-section (and over time) given the inclusion of bank and time fixed effects terms. Note also that the winsorization of the ROE data reduces the impact of extremely negative earning outturns on the results.

${ }^{28}$ Estimates of potential growth are around $1 \frac{1}{2}$ percent, which puts into sharp relief the plausibility of a sustained one standard deviation increase of growth.

${ }^{29}$ For illustrative purposes, two independent shocks are simulated, higher growth and lower NPL ratio-note that their interaction, when introduced into the baseline (quantile) regression specifications is not robustly statistically significant.

${ }^{30}$ In line with the results in Table 9, the regressions in Appendix Table 1 indicate that profitability in the lower ends of the distribution are more sensitive to changes in growth and the NPL ratio.
} 
demonstrating the benefits of a determined reduction of NPLs amid an economic upswing.

\section{Conclusions And Policy Implications}

This paper attempts to shed light on the main determinants of the profitability of larger euro area banks using a novel approach. Specifically, the paper proposes a more probabilistic approach, which places greater emphasis on bank heterogeneity by focusing on bank profitability distributions. To facilitate comparability with the existing literature, the paper first establishes the most reliable determinants of bank profitability across the largest euro area banks. Selected determinants are then shocked to assess how they differentially affect segments of the bank profitability distribution. Specifically, higher economic growth, or a lower NPL ratio, for example, may affect the center of the bank profitability distribution in a different manner relative to how they may influence the tails of the distribution. In this way, the approach in this paper goes beyond the standard comparative statics centered on averages in many studies, and can be particularly insightful.

The empirical analysis reveals that real GDP growth and the NPL ratio are the most reliable medium-term determinants of euro area bank profitability. A key insight of the paper is that although higher growth would raise profits on average, a significant share of banks in the weakest tail of the profitability distribution would most likely continue to struggle, even with a cyclical upswing. Therefore, some banks, in particular, should resolutely address their NPL stocks. In addition, evidence suggests that greater cost efficiency (through digitalization, for example) could enhance profitability of many banks. Although the results on business models were more mixed across all banks, revamping business models could improve profitability for some banks, suggesting the need for custom-tailored approaches. 


\begin{tabular}{|c|c|c|c|c|c|}
\hline \multicolumn{6}{|c|}{$\begin{array}{l}\text { Table 1. Euro Area Bank Sample } \\
\text { (Total Assets in billions of euros) }\end{array}$} \\
\hline Bank & \multicolumn{2}{|r|}{$\begin{array}{r}\text { Total } \\
\text { Assets }\end{array}$} & Bank & \multicolumn{2}{|r|}{$\begin{array}{r}\text { Total } \\
\text { Assets }\end{array}$} \\
\hline Erste Group Bank AG & AT & 217.5 & Bank of Ireland & $\mathrm{IE}$ & 142.6 \\
\hline Raiffeisen Bank International AG & $\mathrm{AT}$ & 124.6 & Allied Irish Banks, plc & $\mathrm{IE}$ & 112.3 \\
\hline BAWAG Holding GmbH & $\mathrm{AT}$ & 38.9 & Ulster Bank Ireland DAC & $\mathrm{IE}$ & 33.8 \\
\hline Sberbank Europe AG & AT & 15.6 & Citibank Europe Plc & $\mathrm{IE}$ & 24.0 \\
\hline Volksbank Wien AG & $\mathrm{AT}$ & 10.9 & UniCredit S.p.A. & IT & 936.8 \\
\hline VTB Bank (Austria) AG & AT & 9.2 & Intesa Sanpaolo S.p.A. & IT & 736.5 \\
\hline KBC Group NV & $\mathrm{BE}$ & 274.7 & Banco BPM S.p.A. & IT & 186.6 \\
\hline Dexia & $\mathrm{BE}$ & 250.7 & Banca Monte dei Paschi di Siena SpA & IT & 184.0 \\
\hline Belfius Bank SA/NV & $\mathrm{BE}$ & 192.7 & Unione di Banche Italiane S.p.A. & IT & 127.6 \\
\hline Argenta B.V.G. NV & $\mathrm{BE}$ & 43.3 & Mediobanca Spa & IT & 79.1 \\
\hline Bank of New York Mellon S.A./N.V. & $\mathrm{BE}$ & 38.6 & BPER Banca S.p.A. & IT & 66.7 \\
\hline AXA Bank Europe & $\mathrm{BE}$ & 33.7 & Iccrea Holding SpA & IT & 53.0 \\
\hline Bank of Cyprus Public Company Limited & $\mathrm{CY}$ & 25.3 & Banca Popolare di Vicenza & IT & 43.3 \\
\hline Cooperative Central Bank Ltd. & $\mathrm{CY}$ & 15.5 & Credito Emiliano S.p.A. & IT & 40.8 \\
\hline RCB Bank Ltd & $\mathrm{CY}$ & 14.6 & Banca Popolare di Sondrio-Societa' Cooperativa per Azioni & IT & 38.7 \\
\hline Hellenic Bank Public Company Limited & $\mathrm{CY}$ & 8.1 & Veneto Banca S.p.A. & IT & 36.3 \\
\hline Swedbank AS & $\mathrm{EE}$ & 10.5 & Banca Carige S.p.A. - Cassa di Risparmio di Genova e Imperia & IT & 33.0 \\
\hline AS SEB Pank & $\mathrm{EE}$ & 5.7 & Swedbank AS (Latvia) & LV & 5.9 \\
\hline Nordea Bank Finland Plc & FI & 328.4 & ABLV Bank AS & LV & 5.4 \\
\hline OP Financial Group & FI & 135.5 & AS SEB Banka & LV & 3.9 \\
\hline Danske Bank PLC & FI & 33.0 & Banque et Caisse d'Epargne de l'Etat & $\mathrm{LU}$ & 46.6 \\
\hline BNP Paribas S.A. & FR & 2171.1 & Precision Capital S.A. & LU & 35.6 \\
\hline Credit Agricole & FR & 1849.6 & JP Morgan Bank Luxembourg S.A. & $\mathrm{LU}$ & 11.3 \\
\hline Credit Mutuel & FR & 805.5 & HSBC Bank Malta plc & MT & 7.9 \\
\hline BPCE S.A. & FR & 788.4 & ING Group & NL & 1094.4 \\
\hline La Banque Postale & FR & 238.1 & Cooperatieve Rabobank U.A. & NL & 739.1 \\
\hline HSBC France & FR & 183.4 & ABN AMRO Group N.V. & NL & 443.5 \\
\hline SFIL & FR & 91.1 & Bank Nederlandse Gemeenten (BNG) & NL & 162.8 \\
\hline Bpifrance Financement S.A. & FR & 48.6 & Nederlandse Waterschapsbank NV & NL & 99.4 \\
\hline Caisse de Refinancement de l'Habitat (CRH) & FR & 46.4 & de Volksbank N.V. & NL & 68.3 \\
\hline RCI Banque & FR & 40.4 & Caixa Geral de Depositos, S.A. & PT & 109.9 \\
\hline Agence Francaise de Developpement (AFD) & FR & 39.0 & Banco Comercial Portugues, S.A. & PT & 81.5 \\
\hline Barclays France SA & FR & 0.0 & Novo Banco, S.A. & PT & 62.6 \\
\hline Deutsche Bank AG & $\mathrm{DE}$ & 1773.7 & Slovenska Sporitelna & SK & 15.2 \\
\hline Commerzbank AG & $\mathrm{DE}$ & 580.0 & Vseobecna Uverova Banka & SK & 13.7 \\
\hline DZ BANK AG Deutsche Zentral-Genossenschaftsbank & $\mathrm{DE}$ & 444.6 & Tatra Banka & SK & 12.2 \\
\hline Landesbank Baden-Wuerttemberg & $\mathrm{DE}$ & 254.8 & Nova Ljubljanska banka d.d. & SI & 12.9 \\
\hline Bayerische Landesbank & $\mathrm{DE}$ & 234.9 & Abanka d.d. & SI & 4.2 \\
\hline Norddeutsche Landesbank Girozentrale & $\mathrm{DE}$ & 197.1 & Banco Santander, S.A. & ES & 1459.2 \\
\hline Landesbank Hessen-Thueringen Girozentrale & $\mathrm{DE}$ & 187.5 & Banco Bilbao Vizcaya Argentaria, S.A. & ES & 816.4 \\
\hline NRW.BANK & $\mathrm{DE}$ & 151.9 & Criteria Caixa, S.A., Unipersonal & ES & 387.5 \\
\hline Volkswagen Financial Services AG & $\mathrm{DE}$ & 132.0 & BFA, Tenedora de Acciones, S.A.U. & ES & 232.7 \\
\hline DekaBank Deutsche Girozentrale & $\mathrm{DE}$ & 117.6 & Banco de Sabadell & ES & 227.1 \\
\hline HSH Nordbank AG & $\mathrm{DE}$ & 105.6 & Banco Popular Espanol S.A. & ES & 172.7 \\
\hline Landwirtschaftliche Rentenbank & $\mathrm{DE}$ & 101.6 & Unicaja Banco S.A. & ES & 65.7 \\
\hline Erwerbsgesellschaft der S-Finanzgruppe mbH \& Co KG & $\mathrm{DE}$ & 81.9 & Ibercaja Banco, S.A. & ES & 64.1 \\
\hline Deutsche Pfandbriefbank AG & $\mathrm{DE}$ & 72.7 & Bankinter & ES & 63.9 \\
\hline Aareal Bank AG & $\mathrm{DE}$ & 56.6 & Kutxabank, S.A. & ES & 63.6 \\
\hline HASPA Finanzholding & $\mathrm{DE}$ & 49.4 & ABANCA Corporacion Bancaria, S.A. & ES & 51.5 \\
\hline Muenchener Hypothekenbank eG & $\mathrm{DE}$ & 41.5 & Liberbank S.A. & ES & 45.9 \\
\hline State Street Bank International GmbH & $\mathrm{DE}$ & 40.9 & Banco Mare Nostrum S.A. & ES & 44.4 \\
\hline Deutsche Apotheker- und Aerztebank eG & $\mathrm{DE}$ & 39.7 & Banco de Credito Social Cooperativo, S.A. & ES & 10.3 \\
\hline SEB AG & $\mathrm{DE}$ & 24.4 & & & \\
\hline National Bank of Greece S.A. & GR & 121.0 & Total assets & & 22804.9 \\
\hline Piraeus Bank S.A. & GR & 95.7 & & & \\
\hline Eurobank Ergasias S.A. & GR & 80.1 & & & \\
\hline Alpha Bank AE & GR & 75.4 & & & \\
\hline $\begin{array}{l}\text { Notes: AT: Austria: BE: Belgium; CY: Cyprt } \\
\text { Luxembourg; MT: Malta; NL: Netherlands; F } \\
\text { number of banks (109) is greatest in the unba }\end{array}$ & Eston & $\begin{array}{l}\text { FI: Fi } \\
\text { : Slov }\end{array}$ & $\begin{array}{l}\text { and; FR: France; DE: Germany; GR: Greece; IT: } \\
\text { kia; ES: Spain. Assets for } 2015 \text { shown because th } \\
\text { le. }\end{array}$ & & $\begin{array}{l}\text { LU: } \\
\text { a the }\end{array}$ \\
\hline
\end{tabular}




\begin{tabular}{|c|c|c|c|c|c|c|c|c|}
\hline \multicolumn{9}{|c|}{ Table 2. Descriptive Statistics of Main Variables } \\
\hline \multirow[b]{2}{*}{ Variable description } & \multirow[b]{2}{*}{ Variable } & \multicolumn{4}{|c|}{ 2007-2016 } & \multicolumn{3}{|c|}{2016} \\
\hline & & \# obs & Median & Mean & SD & Median & Mean & SD \\
\hline Return on average assets & $\mathrm{ROA}$ & 1047 & 0.42 & 0.33 & 1.60 & 0.47 & 0.34 & 1.20 \\
\hline Return on average equity & ROE & 1047 & 8.19 & 2.08 & 49.73 & 8.20 & 4.03 & 15.98 \\
\hline $\log$ (Assets) & $\log \mathrm{A}$ & 1081 & 11.29 & 11.35 & 1.62 & 11.13 & 11.21 & 1.44 \\
\hline Equity/Assets & $\mathrm{E} / \mathrm{A}$ & 1081 & 5.93 & 6.95 & 7.16 & 7.08 & 7.80 & 3.83 \\
\hline Real GDP growth & RGDP growth & 967 & 1.19 & 0.79 & 3.34 & 1.86 & 2.08 & 1.17 \\
\hline 3-month zero coupon yield on AAA euro area securities (ECB) & ECBAAA3M & 1081 & 0.41 & 0.94 & 1.50 & -0.62 & -0.62 & 0.00 \\
\hline Ratio of Nonperforming Loans/Gross Loans & NPLratio & 898 & 4.3 & 7.75 & 9.61 & 4.88 & 10.63 & 13.57 \\
\hline Overhead cost/Operating Income & Costtoincome & 1080 & 59.9 & 35.54 & 743.83 & 62.65 & 66.11 & 23.08 \\
\hline Total Loans/Total Assets & TLTA & 1065 & 62.73 & 58.15 & 22.11 & 64.70 & 59.07 & 20.63 \\
\hline Total Customer Deposits/Total Assets & TDTA & 1045 & 44.76 & 44.69 & 22.11 & 53.06 & 52.12 & 22.27 \\
\hline Noninterest Revenues/Total Operating Income & Nonint/Rev & 1077 & 33.11 & 35.57 & 160.33 & 36.89 & 35.29 & 34.32 \\
\hline Share of 5-largest bank assets in total bank assets (Country-specific) & Largest5 & 1081 & 47.4 & 52.03 & 19.76 & 45.95 & 54.44 & 18.95 \\
\hline
\end{tabular}

\begin{tabular}{|lrrrr|}
\hline \multicolumn{5}{c|}{ Table 3. Stylized Facts: Key Bank-Specific Determinants } \\
\hline \multicolumn{4}{c}{ ROE quintile bucke ts } \\
\hline ROE & $<$ Q1 & Q1-Q2 & Q2-Q3 & $>\mathbf{Q 3}$ \\
ROA & -16.3 & 5.7 & 9.9 & 15.3 \\
Equity-to-assets & -1.1 & 0.4 & 0.8 & 1.3 \\
Total as sets (trillions of euros) & 8.3 & 7.4 & 7.7 & 8.5 \\
NPL ratio & 4.1 & 5.0 & 8.3 & 3.5 \\
Cost-to-income ratio & 22.3 & 11.2 & 5.3 & 4.2 \\
Loans-to-assets & 81.2 & 70.2 & 61.7 & 52.2 \\
Deposits-to-assets & 67.9 & 58.7 & 51.1 & 66.0 \\
Source: & FitchConnect, ECB, and IMF staff calculations. \\
Notes: The numbers in the columns are the mean of the variables in each quintile bucket, which is based on the distribution of the ROE \\
across banks in 2016.
\end{tabular}




\begin{tabular}{|c|c|c|c|c|c|c|}
\hline \multicolumn{7}{|c|}{ Table 4. Baseline Profitability Regressions: Return on Assets and Components } \\
\hline VARIABLES & $\begin{array}{c}(1) \\
\text { ROA }\end{array}$ & $\begin{array}{c}(2) \\
\text { Net Interest } \\
\text { Income/Assets } \\
\end{array}$ & $\begin{array}{c}\text { (3) } \\
\text { Noninterest } \\
\text { income/Assets } \\
\end{array}$ & $\begin{array}{c}\text { (4) } \\
\text { Loan loss } \\
\text { provisions/Assets }\end{array}$ & $\begin{array}{c}\text { (5) } \\
\text { Cost/Assets }\end{array}$ & $\begin{array}{c}(6) \\
\text { Pre-provision } \\
\text { ROA } \\
\end{array}$ \\
\hline Size (log as sets) & $\begin{array}{c}-0.532 * * \\
(0.2590)\end{array}$ & $\begin{array}{c}-0.106 \\
(0.0969)\end{array}$ & $\begin{array}{c}-0.265 * * * \\
(0.0667)\end{array}$ & $\begin{array}{c}0.210 \\
(0.2520)\end{array}$ & $\begin{array}{c}0.0007 \\
(0.0711)\end{array}$ & $\begin{array}{c}-0.457 * * * \\
(0.1480)\end{array}$ \\
\hline Equity-to-assets & $\begin{array}{c}0.0314 \\
(0.0454)\end{array}$ & $\begin{array}{c}0.0446^{* * * *} \\
(0.0079)\end{array}$ & $\begin{array}{l}-0.00335 \\
(0.0069)\end{array}$ & $\begin{array}{l}-0.0138 \\
(0.0384)\end{array}$ & $\begin{array}{l}0.00969 \\
(0.0069)\end{array}$ & $\begin{array}{c}0.0126 \\
(0.0210)\end{array}$ \\
\hline GDP growth & $\begin{array}{c}0.272 * * * \\
(0.0681)\end{array}$ & $\begin{array}{l}0.00542 \\
(0.0077)\end{array}$ & $\begin{array}{l}0.0111^{*} \\
(0.0062)\end{array}$ & $\begin{array}{c}-0.199 * * * \\
(0.0348)\end{array}$ & $\begin{array}{r}-0.00565 \\
(0.0054)\end{array}$ & $\begin{array}{c}0.0730 \\
(0.0474)\end{array}$ \\
\hline NPL ratio & $\begin{array}{c}-0.0457 * * \\
(0.0217)\end{array}$ & $\begin{array}{l}-0.00407 \\
(0.0042)\end{array}$ & $\begin{array}{c}-0.000394 \\
(0.0044)\end{array}$ & $\begin{array}{l}0.0283^{*} \\
(0.0167)\end{array}$ & $\begin{array}{c}0.0092 * * * \\
(0.0031)\end{array}$ & $\begin{array}{l}-0.0168 * \\
(0.0086)\end{array}$ \\
\hline Cost-to-income & $\begin{array}{l}-0.00304 \\
(0.0022)\end{array}$ & $\begin{array}{c}-0.00139 * * * \\
(0.0005)\end{array}$ & $\begin{array}{l}0.000141 \\
(0.0004)\end{array}$ & $\begin{array}{l}0.00173 \\
(0.0017)\end{array}$ & $\begin{array}{c}0.0000 \\
(0.0004)\end{array}$ & $\begin{array}{l}-0.00150 \\
(0.0009)\end{array}$ \\
\hline Loans-to-assets & $\begin{array}{l}-0.0134 \\
(0.0141)\end{array}$ & $\begin{array}{c}0.00609^{* *} \\
(0.0026)\end{array}$ & $\begin{array}{c}-0.000838 \\
(0.0022)\end{array}$ & $\begin{array}{c}0.0194 \\
(0.0124)\end{array}$ & $\begin{array}{c}0.00391 * * \\
(0.0017)\end{array}$ & $\begin{array}{l}0.00490 \\
(0.0049)\end{array}$ \\
\hline Deposits-to-assets & $\begin{array}{l}0.00791 \\
(0.0106)\end{array}$ & $\begin{array}{c}0.00501^{*} \\
(0.0026)\end{array}$ & $\begin{array}{l}0.00229 \\
(0.0026)\end{array}$ & $\begin{array}{c}-0.0160 * * \\
(0.0080)\end{array}$ & $\begin{array}{c}0.0061^{* * *} \\
(0.0016)\end{array}$ & $\begin{array}{l}-0.00860 \\
(0.0060)\end{array}$ \\
\hline Noninterest income & $\begin{array}{l}-0.00206 \\
(0.0016)\end{array}$ & $\begin{array}{c}-0.00108 * * \\
(0.0004)\end{array}$ & $\begin{array}{l}0.000348 \\
(0.0003)\end{array}$ & $\begin{array}{l}0.0013 \\
(0.0012)\end{array}$ & $\begin{array}{l}0.0000 \\
(0.0003)\end{array}$ & $\begin{array}{c}-0.000885 \\
(0.0007)\end{array}$ \\
\hline Concentration & $\begin{array}{l}-0.00937 \\
(0.0213)\end{array}$ & $\begin{array}{l}-0.00421 \\
(0.0043)\end{array}$ & $\begin{array}{l}0.00116 \\
(0.0042)\end{array}$ & $\begin{array}{l}0.0218^{*} \\
(0.0126)\end{array}$ & $\begin{array}{l}(0.0003) \\
(0.0030)\end{array}$ & $\begin{array}{c}0.0132 \\
(0.0139)\end{array}$ \\
\hline Observations & 794 & 794 & 794 & 791 & 795 & 791 \\
\hline R-squared & 0.482 & 0.904 & 0.662 & 0.480 & 0.855 & 0.534 \\
\hline
\end{tabular}




\begin{tabular}{|c|c|c|c|c|c|c|c|c|}
\hline \multicolumn{9}{|c|}{ Table 5. Robustness Analysis: Return on Assets } \\
\hline & $(1)$ & (2) & (3) & (4) & (5) & (6) & (Balanced) & (GMM) \\
\hline Size (log as sets) & $\begin{array}{c}-0.532 * * \\
(0.259)\end{array}$ & $\begin{array}{c}-0.587 * * \\
(0.244)\end{array}$ & $\begin{array}{c}-0.570^{*} \\
(0.296)\end{array}$ & $\begin{array}{c}-0.557^{*} \\
(0.283)\end{array}$ & $\begin{array}{c}-1.211 * * * \\
(0.448)\end{array}$ & $\begin{array}{c}-0.482 * \\
(0.252)\end{array}$ & $\begin{array}{c}-0.741 * * \\
(0.333)\end{array}$ & $\begin{array}{c}0.810 \\
(0.662)\end{array}$ \\
\hline Equity-to-assets & $\begin{array}{c}0.0314 \\
(0.0454)\end{array}$ & $\begin{array}{l}0.00611 \\
(0.0460)\end{array}$ & $\begin{array}{c}0.0571 \\
(0.0582)\end{array}$ & $\begin{array}{c}0.0103 \\
(0.0560)\end{array}$ & $\begin{array}{l}-0.0680 \\
(0.0644)\end{array}$ & $\begin{array}{c}0.0460 \\
(0.0442)\end{array}$ & $\begin{array}{c}0.0734 \\
(0.0702)\end{array}$ & $\begin{array}{c}0.322 * * * \\
(0.0591)\end{array}$ \\
\hline GDP growth & $\begin{array}{c}0.272 * * * \\
(0.0681)\end{array}$ & $\begin{array}{c}0.187 * * * \\
(0.0710)\end{array}$ & $\begin{array}{c}0.269 * * * \\
(0.0729)\end{array}$ & $\begin{array}{l}0.225^{* *} \\
(0.0878)\end{array}$ & $\begin{array}{c}0.306^{* *} \\
(0.121)\end{array}$ & $\begin{array}{c}0.177 * * * \\
(0.0360)\end{array}$ & $\begin{array}{c}0.353 * * * \\
(0.114)\end{array}$ & $\begin{array}{c}0.159 * * * \\
(0.0388)\end{array}$ \\
\hline NPL ratio & $\begin{array}{c}-0.0457 * * \\
(0.0217)\end{array}$ & $\begin{array}{c}-0.0711 * * * \\
(0.0196)\end{array}$ & $\begin{array}{c}-0.0557 * * * \\
(0.0203)\end{array}$ & $\begin{array}{c}-0.0568 * * \\
(0.0270)\end{array}$ & $\begin{array}{c}-0.0622 * * \\
(0.0262)\end{array}$ & $\begin{array}{r}-0.0426^{*} \\
(0.0223)\end{array}$ & $\begin{array}{c}-0.0695^{* * *} * \\
(0.0232)\end{array}$ & $\begin{array}{c}-0.0847 * * * \\
(0.0219)\end{array}$ \\
\hline Cost-to-income & $\begin{array}{l}-0.00304 \\
(0.00219)\end{array}$ & $\begin{array}{l}-0.00165 \\
(0.00230)\end{array}$ & $\begin{array}{l}-0.000487 \\
(0.00313)\end{array}$ & $\begin{array}{l}-0.00200 \\
(0.00246)\end{array}$ & $\begin{array}{l}-0.000104 \\
(0.00282)\end{array}$ & $\begin{array}{c}-0.00375^{*} \\
(0.00221)\end{array}$ & $\begin{array}{l}-0.00332 \\
(0.00370)\end{array}$ & $\begin{array}{c}-0.0109 * * \\
(0.00479)\end{array}$ \\
\hline Loans-to-assets & $\begin{array}{l}-0.0134 \\
(0.0141)\end{array}$ & $\begin{array}{l}-0.00435 \\
(0.0142)\end{array}$ & $\begin{array}{l}-0.0152 \\
(0.0180)\end{array}$ & $\begin{array}{l}-0.00455 \\
(0.0178)\end{array}$ & $\begin{array}{l}-0.00552 \\
(0.0241)\end{array}$ & $\begin{array}{l}-0.0156 \\
(0.0137)\end{array}$ & $\begin{array}{l}-0.0193 \\
(0.0166)\end{array}$ & $\begin{array}{l}-0.0122 \\
(0.0220)\end{array}$ \\
\hline Deposits-to-assets & $\begin{array}{l}0.00791 \\
(0.0106)\end{array}$ & $\begin{array}{l}-0.00275 \\
(0.00944)\end{array}$ & $\begin{array}{l}0.00190 \\
(0.0129)\end{array}$ & $\begin{array}{l}0.00309 \\
(0.0133)\end{array}$ & $\begin{array}{c}0.00833 \\
(0.00928)\end{array}$ & $\begin{array}{c}0.0114 \\
(0.0105)\end{array}$ & $\begin{array}{l}-0.00433 \\
(0.0181)\end{array}$ & $\begin{array}{c}0.0302 * * \\
(0.0150)\end{array}$ \\
\hline Noninterest income & $\begin{array}{l}-0.00206 \\
(0.00161)\end{array}$ & $\begin{array}{l}-0.00112 \\
(0.00166)\end{array}$ & $\begin{array}{l}-0.000100 \\
(0.00240)\end{array}$ & $\begin{array}{l}-0.00129 \\
(0.00184)\end{array}$ & $\begin{array}{l}0.000104 \\
(0.00210)\end{array}$ & $\begin{array}{l}-0.00227 \\
(0.00164)\end{array}$ & $\begin{array}{l}-0.00207 \\
(0.00276)\end{array}$ & $\begin{array}{c}-0.00930 * * * \\
(0.00321)\end{array}$ \\
\hline Concentration & $\begin{array}{l}-0.00937 \\
(0.0213)\end{array}$ & $\begin{array}{l}0.00835 \\
(0.0198)\end{array}$ & $\begin{array}{l}-0.00401 \\
(0.0273)\end{array}$ & $\begin{array}{c}0.0118 \\
(0.0226)\end{array}$ & $\begin{array}{l}-0.0166 \\
(0.0197)\end{array}$ & $\begin{array}{l}-0.0159 \\
(0.0223)\end{array}$ & $\begin{array}{l}0.00193 \\
(0.0234)\end{array}$ & $\begin{array}{r}-0.00431 \\
(0.0210)\end{array}$ \\
\hline NPL ratio, change & & $\begin{array}{l}-0.154 * * \\
(0.0607)\end{array}$ & & & & & & \\
\hline Loan growth & & & $\begin{array}{c}-1.78 \mathrm{e}-06 \\
(1.90 \mathrm{e}-06)\end{array}$ & & & & & \\
\hline FCI & & & & $\begin{array}{c}-0.390 * * \\
(0.174)\end{array}$ & & & & \\
\hline Yield curve slope & & & & & $\begin{array}{l}-0.0140 \\
(0.0265)\end{array}$ & & & \\
\hline Policy rate & & & & & & $\begin{array}{c}0.0392 \\
(0.0474)\end{array}$ & & \\
\hline ROA (lag) & & & & & & & & $\begin{array}{l}-0.172 \\
(0.110)\end{array}$ \\
\hline Observations & 794 & 787 & 718 & 650 & 545 & 794 & 444 & 696 \\
\hline R-squared & 0.482 & 0.545 & 0.486 & 0.467 & 0.489 & 0.433 & 0.548 & \\
\hline $\begin{array}{l}\text { Bank and year FE; } \mathrm{st} \\
\text { explanatory variable, } \\
* * * \mathrm{p}<0.01, * * \mathrm{p}<0.0\end{array}$ & $\begin{array}{l}\text { lustered } \\
\text { itability, }\end{array}$ & $\begin{array}{l}\text { by country" } \\
\text { is lagged. }\end{array}$ & *year. Colur & $\mathrm{mn}(6)$ does & es not have & ear FE. Fo & pr the GMM & $\overline{\text { column, no }}$ \\
\hline
\end{tabular}




\begin{tabular}{|c|c|c|c|c|c|c|c|c|}
\hline \multicolumn{9}{|c|}{ Table 6. Return on Equity Regressions } \\
\hline & $(1)$ & $(2)$ & (3) & (4) & (5) & (6) & (Balanced) & $(\mathrm{GMM})$ \\
\hline Size (log assets) & $\begin{array}{l}-5.923 \\
(12.44)\end{array}$ & $\begin{array}{l}-7.337 \\
(12.29)\end{array}$ & $\begin{array}{l}-14.83 \\
(14.98)\end{array}$ & $\begin{array}{l}-2.610 \\
(16.47)\end{array}$ & $\begin{array}{l}-24.68 \\
(23.63)\end{array}$ & $\begin{array}{l}-4.493 \\
(11.40)\end{array}$ & $\begin{array}{l}-15.44 \\
(12.67)\end{array}$ & $\begin{array}{c}19.71 \\
(21.30)\end{array}$ \\
\hline Equity-to-assets & $\begin{array}{c}-0.0338 \\
(1.392)\end{array}$ & $\begin{array}{l}-0.578 \\
(1.323)\end{array}$ & $\begin{array}{c}0.815 \\
(1.946)\end{array}$ & $\begin{array}{l}-0.0794 \\
(1.921)\end{array}$ & $\begin{array}{l}-1.581 \\
(1.671)\end{array}$ & $\begin{array}{c}0.567 \\
(1.477)\end{array}$ & $\begin{array}{l}-0.866 \\
(2.174)\end{array}$ & $\begin{array}{l}7.073 * \\
(3.729)\end{array}$ \\
\hline GDP growth & $\begin{array}{c}4.329 * * \\
(1.681)\end{array}$ & $\begin{array}{c}2.502 \\
(1.619)\end{array}$ & $\begin{array}{c}3.842 * * \\
(1.707)\end{array}$ & $\begin{array}{c}3.452 \\
(2.286)\end{array}$ & $\begin{array}{c}4.596 \\
(3.328)\end{array}$ & $\begin{array}{c}2.915^{* * *} \\
(0.812)\end{array}$ & $\begin{array}{l}5.671^{*} \\
(2.937)\end{array}$ & $\begin{array}{l}1.551^{*} \\
(0.872)\end{array}$ \\
\hline NPL ratio & $\begin{array}{l}-0.416 \\
(0.422)\end{array}$ & $\begin{array}{c}-0.961^{* *} \\
(0.383)\end{array}$ & $\begin{array}{c}-0.728^{* *} \\
(0.364)\end{array}$ & $\begin{array}{l}-0.890^{*} \\
(0.516)\end{array}$ & $\begin{array}{l}-1.180^{*} \\
(0.699)\end{array}$ & $\begin{array}{l}-0.378 \\
(0.419)\end{array}$ & $\begin{array}{c}-0.836^{* *} \\
(0.359)\end{array}$ & $\begin{array}{c}-1.682 * * \\
(0.721)\end{array}$ \\
\hline Cost-to-income & $\begin{array}{l}0.0523 \\
(0.119)\end{array}$ & $\begin{array}{l}0.0814 \\
(0.115)\end{array}$ & $\begin{array}{c}0.109 \\
(0.244)\end{array}$ & $\begin{array}{l}0.0708 \\
(0.141)\end{array}$ & $\begin{array}{l}0.0772 \\
(0.169)\end{array}$ & $\begin{array}{l}0.0199 \\
(0.118)\end{array}$ & $\begin{array}{c}-0.114 \\
(0.0807)\end{array}$ & $\begin{array}{l}-0.248 \\
(0.325)\end{array}$ \\
\hline Loans-to-assets & $\begin{array}{c}0.217 \\
(0.527)\end{array}$ & $\begin{array}{c}0.405 \\
(0.531)\end{array}$ & $\begin{array}{l}-0.0411 \\
(0.678)\end{array}$ & $\begin{array}{c}0.431 \\
(0.791)\end{array}$ & $\begin{array}{l}-0.0328 \\
(1.401)\end{array}$ & $\begin{array}{c}0.128 \\
(0.508)\end{array}$ & $\begin{array}{l}-0.0880 \\
(0.383)\end{array}$ & $\begin{array}{l}1.704^{*} \\
(1.012)\end{array}$ \\
\hline Deposits-to-assets & $\begin{array}{c}0.137 \\
(0.279)\end{array}$ & $\begin{array}{l}-0.0976 \\
(0.274)\end{array}$ & $\begin{array}{l}-0.0723 \\
(0.263)\end{array}$ & $\begin{array}{l}0.0692 \\
(0.362)\end{array}$ & $\begin{array}{c}0.301 \\
(0.389)\end{array}$ & $\begin{array}{c}0.287 \\
(0.310)\end{array}$ & $\begin{array}{l}-0.232 \\
(0.296)\end{array}$ & $\begin{array}{c}0.709 \\
(0.596)\end{array}$ \\
\hline Noninterest income & $\begin{array}{c}0.0379 \\
(0.0866)\end{array}$ & $\begin{array}{c}0.0575 \\
(0.0829)\end{array}$ & $\begin{array}{l}0.0757 \\
(0.180)\end{array}$ & $\begin{array}{l}0.0522 \\
(0.102)\end{array}$ & $\begin{array}{l}0.0577 \\
(0.123)\end{array}$ & $\begin{array}{c}0.0235 \\
(0.0852)\end{array}$ & $\begin{array}{l}-0.0841 \\
(0.0632)\end{array}$ & $\begin{array}{l}-0.178 \\
(0.246)\end{array}$ \\
\hline Concentration & $\begin{array}{c}0.425 \\
(0.526)\end{array}$ & $\begin{array}{c}0.810 \\
(0.514)\end{array}$ & $\begin{array}{c}0.579 \\
(0.715)\end{array}$ & $\begin{array}{c}0.930 \\
(0.661)\end{array}$ & $\begin{array}{c}0.936 \\
(0.896)\end{array}$ & $\begin{array}{c}0.373 \\
(0.556)\end{array}$ & $\begin{array}{c}0.135 \\
(0.470)\end{array}$ & $\begin{array}{c}0.112 \\
(0.661)\end{array}$ \\
\hline NPL ratio, change & & $\begin{array}{c}-3.318 * * * \\
(1.082)\end{array}$ & & & & & & \\
\hline Loan growth & & & $\begin{array}{l}-8.08 \mathrm{e}-06 \\
(4.33 \mathrm{e}-05)\end{array}$ & & & & & \\
\hline FCI & & & & $\begin{array}{l}-9.982 \\
(8.820)\end{array}$ & & & & \\
\hline Yield curve slope & & & & & $\begin{array}{l}0.0759 \\
(1.478)\end{array}$ & & & \\
\hline Policy rate & & & & & & $\begin{array}{c}2.366 \\
(1.511)\end{array}$ & & \\
\hline ROE (lag) & & & & & & & & $\begin{array}{l}-0.0417 \\
(0.0602)\end{array}$ \\
\hline Observations & 794 & 787 & 718 & 650 & 545 & 794 & 444 & 696 \\
\hline R-squared & 0.220 & 0.246 & 0.217 & 0.207 & 0.224 & 0.189 & 0.360 & \\
\hline
\end{tabular}




\begin{tabular}{|c|c|c|c|c|}
\hline \multicolumn{5}{|c|}{ Table 8. Quantile Regressions: Return on Assets } \\
\hline & \multirow{2}{*}{$\frac{\text { OLS }}{(1)}$} & $(2)$ & $(3)$ & ois \\
\hline VARIABLES & & 25 th & 50 th & 75th \\
\hline Size (log assets) & $\begin{array}{c}-0.532 * * \\
(0.259)\end{array}$ & $\begin{array}{l}-0.221 \\
(0.316)\end{array}$ & $\begin{array}{l}-0.111 \\
(0.216)\end{array}$ & $\begin{array}{c}-0.252^{* *} \\
(0.117)\end{array}$ \\
\hline Equity-to-assets & $\begin{array}{c}0.0314 \\
(0.0454)\end{array}$ & $\begin{array}{c}0.0229 \\
(0.0279)\end{array}$ & $\begin{array}{c}0.0504 * * * \\
(0.0191)\end{array}$ & $\begin{array}{c}0.0439 * * * \\
(0.0103)\end{array}$ \\
\hline GDP growth & $\begin{array}{c}0.272 * * * \\
(0.0681)\end{array}$ & $\begin{array}{c}0.201 * * * \\
(0.0258)\end{array}$ & $\begin{array}{c}0.135 * * * \\
(0.0176)\end{array}$ & $\begin{array}{c}0.0864 * * * \\
(0.00955)\end{array}$ \\
\hline NPL ratio & $\begin{array}{c}-0.0457 * * \\
(0.0217)\end{array}$ & $\begin{array}{c}-0.0752^{* * *} * \\
(0.0113)\end{array}$ & $\begin{array}{c}-0.0455^{* * *} * \\
(0.00772)\end{array}$ & $\begin{array}{c}-0.0103 * * \\
(0.00418)\end{array}$ \\
\hline Cost-to-income & $\begin{array}{l}-0.00304 \\
(0.00219)\end{array}$ & $\begin{array}{l}-0.00202 \\
(0.00192)\end{array}$ & $\begin{array}{c}-0.00312 * * \\
(0.00131)\end{array}$ & $\begin{array}{c}-0.00192 * * * \\
(0.000710)\end{array}$ \\
\hline Loans-to-assets & $\begin{array}{l}-0.0134 \\
(0.0141)\end{array}$ & $\begin{array}{c}-0.0118 \\
(0.00953)\end{array}$ & $\begin{array}{l}-0.00949 \\
(0.00650)\end{array}$ & $\begin{array}{l}-0.00639 * \\
(0.00352)\end{array}$ \\
\hline Deposits-to-as sets & $\begin{array}{l}0.00791 \\
(0.0106)\end{array}$ & $\begin{array}{c}0.00837 \\
(0.00985)\end{array}$ & $\begin{array}{c}0.00531 \\
(0.00672)\end{array}$ & $\begin{array}{c}0.00888 * * \\
(0.00364)\end{array}$ \\
\hline Noninterest income & $\begin{array}{l}-0.00206 \\
(0.00161)\end{array}$ & $\begin{array}{l}-0.00122 \\
(0.00150)\end{array}$ & $\begin{array}{c}-0.00230^{* *} \\
(0.00102)\end{array}$ & $\begin{array}{r}-0.00145^{* * *} * \\
(0.000553)\end{array}$ \\
\hline Concentration & $\begin{array}{r}-0.00937 \\
(0.0213)\end{array}$ & $\begin{array}{l}-0.0171 \\
(0.0135)\end{array}$ & $\begin{array}{c}-0.0142 \\
(0.00921)\end{array}$ & $\begin{array}{c}-0.0148^{* * *} \\
(0.00499)\end{array}$ \\
\hline Observations & 794 & 798 & 798 & 798 \\
\hline $\begin{array}{l}\text { Notes: Bank and yea } \\
\text { Standard errors in p } \\
* * * \mathrm{p}<0.01, * * \mathrm{p}<0 .\end{array}$ & $\begin{array}{l}\text { effects no } \\
\text { ses } \\
0.1\end{array}$ & & & \\
\hline
\end{tabular}


Table 10. Summary: Conditional Profitability (ROE) Distributions (In percent)

\begin{tabular}{lcc}
\hline ROE Threshold: & $<8$ & $>8$ \\
Baseline & 82.5 & 17.5 \\
Higher Growth & 61.4 & 38.6 \\
Lower NPLs & 71.9 & 28.1 \\
Higher groth and Lower NPLs & 49.1 & 50.9 \\
& & \\
\hline Descriptive statistics & Mean & Standard deviation \\
Growth & 0.8 & 3.3 \\
NPL & 7.4 & 8.9 \\
\hline
\end{tabular}

Source: Authors' calculations.

Notes: Return on equity (ROE) is the measure of profitability used. The table displays to probability of ROE being less (greater) than 8 percent. These probabilities are calculated using the baseline and shocked distributions, where 1 standard deviation shocks are used. Selected sample descriptive statistics are included. 


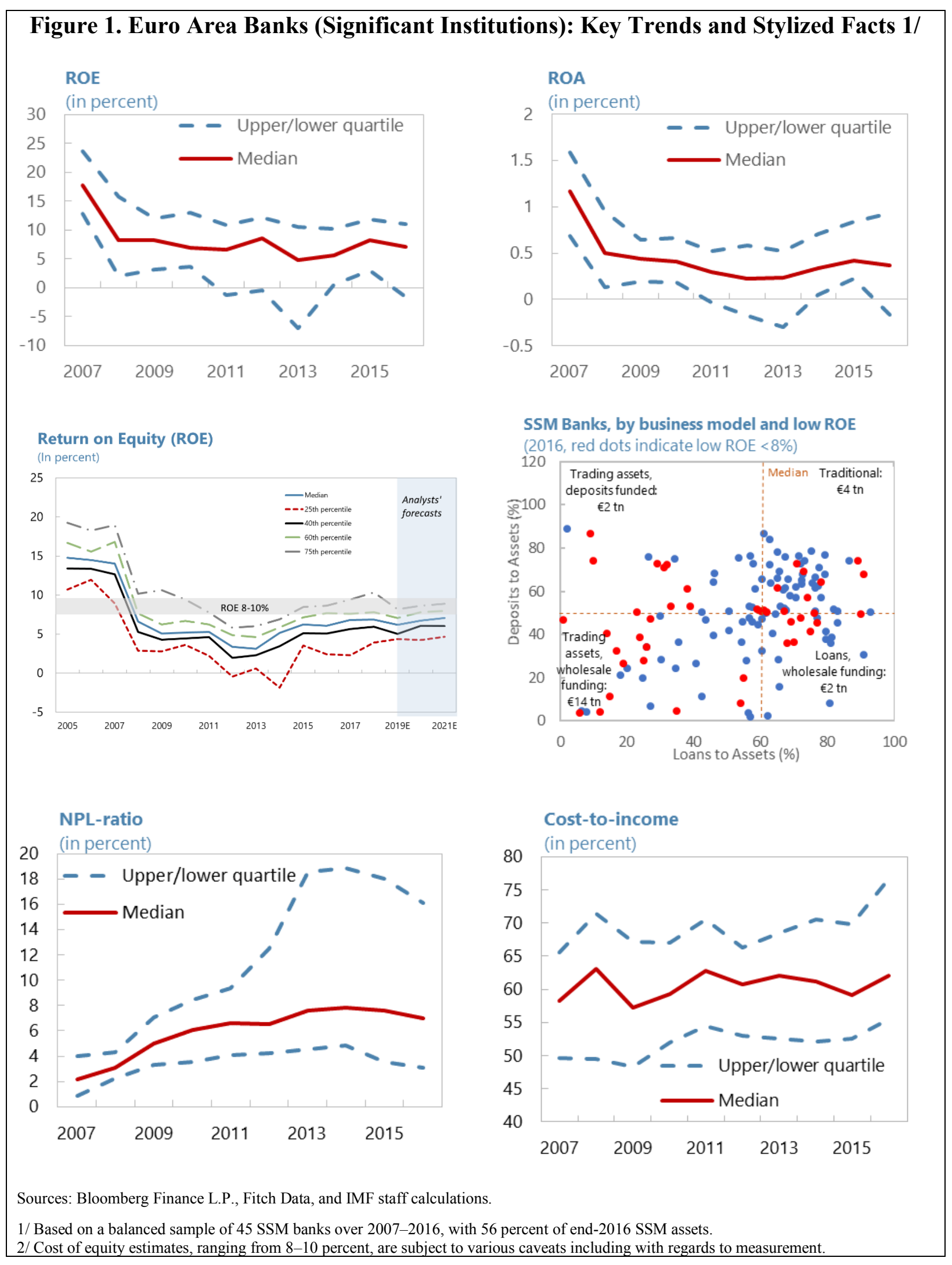

CInternational Monetary Fund. Not for Redistribution 


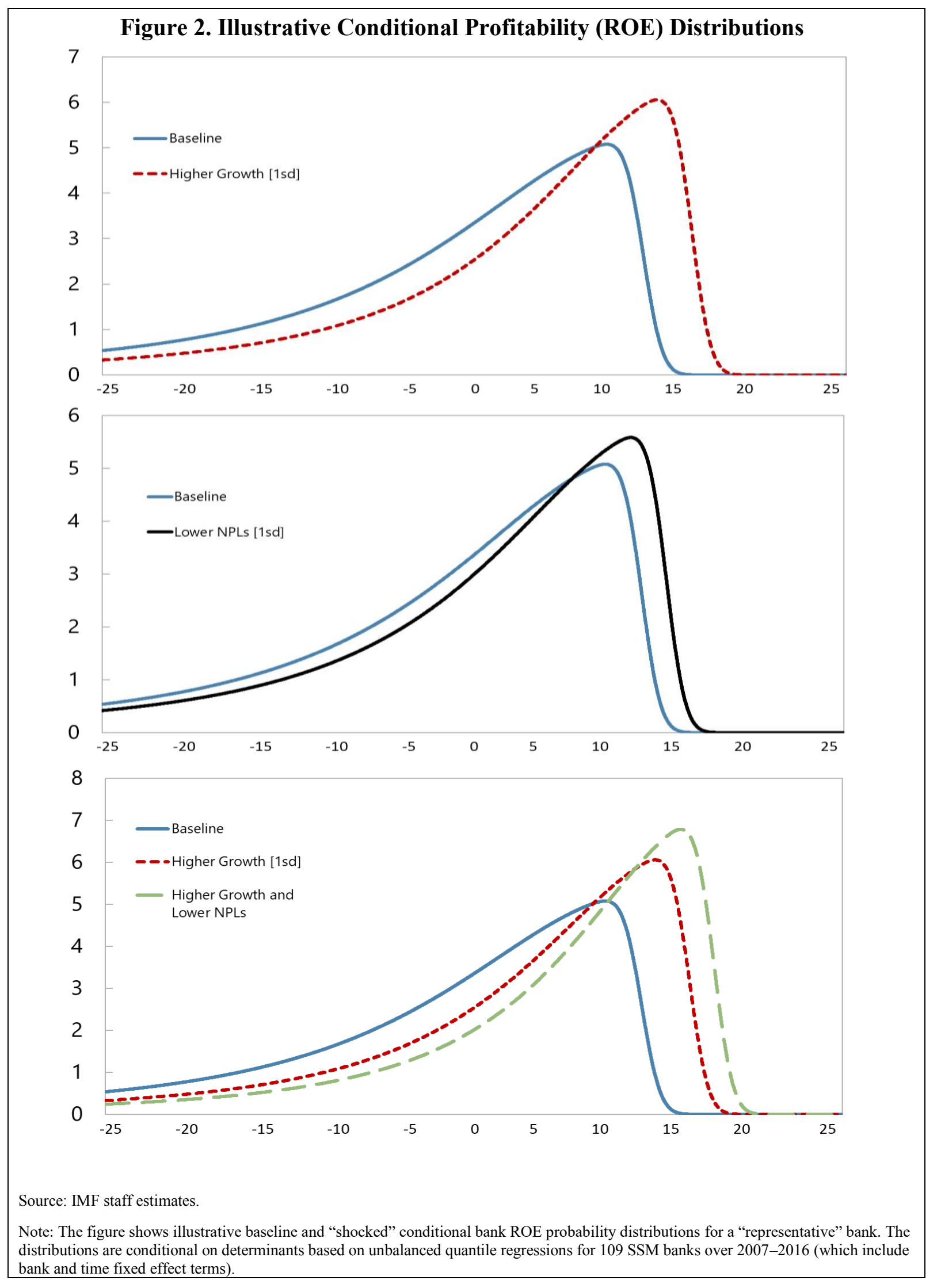

CInternational Monetary Fund. Not for Redistribution 


\begin{tabular}{|c|c|c|c|c|c|c|c|c|c|}
\hline \multicolumn{10}{|c|}{ Appendix Table 1. Quantile Regressions: Return on Equity } \\
\hline \multirow[b]{2}{*}{ VARIABLES } & (1) & (2) & (3) & (4) & (5) & (6) & (7) & (8) & (9) \\
\hline & 10th & 20th & 30th & 40th & 50th & 60th & 70th & 80th & 90th \\
\hline \multirow[t]{2}{*}{$\log A_{-} 1$} & -7.726 & -8.229 & -6.564 & -4.563 & -4.409 & -3.668 & -3.470 & -4.166 & -6.617 \\
\hline & $(4.49)$ & $(3.21)$ & $(2.39)$ & $(1.47)$ & $(2.62)$ & $(1.36)$ & $(1.02)$ & $(1.18)$ & $(1.81)$ \\
\hline \multirow[t]{2}{*}{ equitytotalassets_1 } & -0.146 & 0.122 & 0.190 & -0.034 & -0.186 & -0.274 & -0.453 & -0.627 & -1.061 \\
\hline & $(0.40)$ & $(0.28)$ & $(0.21)$ & $(0.13)$ & $(0.23)$ & $(0.12)$ & $(0.09)$ & $(0.10)$ & $(0.16)$ \\
\hline \multirow[t]{2}{*}{ gdpgrowth } & 2.678 & 2.488 & 2.277 & 1.916 & 1.681 & 1.378 & 1.064 & 1.001 & 0.965 \\
\hline & $(0.37)$ & $(0.26)$ & $(0.20)$ & $(0.12)$ & $(0.21)$ & $(0.11)$ & $(0.08)$ & $(0.10)$ & $(0.15)$ \\
\hline \multirow[t]{2}{*}{ nplratio_1 } & -0.542 & -0.414 & -0.451 & -0.472 & -0.464 & -0.215 & -0.160 & -0.137 & -0.180 \\
\hline & $(0.16)$ & $(0.12)$ & $(0.09)$ & $(0.05)$ & $(0.09)$ & $(0.05)$ & $(0.04)$ & $(0.04)$ & $(0.06)$ \\
\hline \multirow[t]{2}{*}{ costtoincome_1 } & -0.006 & -0.026 & -0.031 & -0.013 & -0.009 & 0.002 & 0.013 & 0.020 & 0.035 \\
\hline & $(0.03)$ & $(0.02)$ & $(0.01)$ & $(0.01)$ & $(0.02)$ & $(0.01)$ & $(0.01)$ & $(0.01)$ & $(0.01)$ \\
\hline \multirow[t]{2}{*}{ loanstoassets_1 } & -0.131 & -0.156 & -0.102 & -0.103 & -0.130 & -0.110 & -0.123 & -0.092 & -0.101 \\
\hline & $(0.14)$ & $(0.10)$ & $(0.07)$ & $(0.04)$ & $(0.08)$ & $(0.04)$ & $(0.03)$ & $(0.04)$ & $(0.05)$ \\
\hline \multirow[t]{2}{*}{ depositstoassets_1 } & 0.089 & 0.064 & 0.022 & 0.021 & 0.022 & 0.094 & 0.130 & 0.083 & 0.084 \\
\hline & $(0.14)$ & $(0.10)$ & $(0.07)$ & $(0.05)$ & $(0.08)$ & $(0.04)$ & $(0.03)$ & $(0.04)$ & $(0.06)$ \\
\hline \multirow[t]{2}{*}{ noninterestincomegrossrevenues_1 } & -0.021 & -0.033 & -0.021 & -0.010 & -0.008 & 0.000 & 0.007 & 0.012 & 0.024 \\
\hline & $(0.02)$ & $(0.02)$ & $(0.01)$ & $(0.01)$ & $(0.01)$ & $(0.01)$ & $(0.00)$ & $(0.01)$ & $(0.01)$ \\
\hline \multirow[t]{2}{*}{ largest5 } & -0.199 & -0.292 & -0.258 & -0.196 & -0.222 & -0.179 & -0.155 & -0.140 & -0.146 \\
\hline & $(0.19)$ & $(0.14)$ & $(0.10)$ & $(0.06)$ & $(0.11)$ & $(0.06)$ & $(0.04)$ & $(0.05)$ & $(0.08)$ \\
\hline Observations & 798 & 798 & 798 & 798 & 798 & 798 & 798 & 798 & 798 \\
\hline
\end{tabular}




\section{REFERENCES}

Adrian, T., Boyarchenko, N., Giannone, D., (2019), "Vulnerable Growth," American Economic Review, 109(4): 1263-89.

Akerlof, G.A., P.M. Romer, R.E. Hall, and N.G. Mankiw, (1993), "Looting: The Economic Underworld of Bankruptcy for Profit,” Brookings Papers and Economic Activity, 1993(2): $1-73$.

Altavilla, C., M. Bouchinha, and J-L. Peydro, (2018), "Monetary Policy and Bank Profitability in a Low Interest Rate Environment," Economic Policy, 33(96): 531-86.

Alessandri, P., and B.D. Nelson, (2015), "Simple Banking: Profitability and the Yield Curve," Journal of Money, Credit and Banking, 47(1): 143-75.

Albertazzi, U., Gambacorta, L., (2009), "Bank profitability and the business cycle," Journal of Financial Stability, 5(4): 393-409.

Altunbas, Y., Manganelli, S., and Marquez-Ibanez, D., (2011), "Bank Risk During the Financial Crisis: Do Business Models Matter?” ECB Working Paper, 1394.

Arellano, M., Bond, S., (1991), "Some Tests of Specification for Panel Data: Monte Carlo Evidence and an Application to Employment Equations," The Review of Economic Studies, 58(2): 277297.

Arregui, N., Elekdag, S., Gelos, G., Lafarguette, R., Seneviratne, D., (2018), “Can Countries Manage Their Financial Conditions Amid Globalization?” IMF Working Paper, 18/15.

Ayadi Sami Ben, R., Naceur; Casu, B., Quinn, B., (2015), "Does Basel Compliance Matter for Bank Performance?" IMF Working Paper, 15/100.

Azzalini, A. and Capitanio, A. (2003), "Distributions generated by perturbation of symmetry with emphasis on a multivariate skew $t$-distribution." Journal of the Royal Statistical Society: Series B (Statistical Methodology), 65: 367-389.

Barth J. R., G. Caprio, and R. Levine, (2006), "Bank Regulation and Supervision: What Works Best?" Journal of Financial Intermediation, 13: 205-48.

Barth J. R., Caprio, C., Levine, R., (2006), Rethinking Bank Regulation: Till Angels Govern, Cambridge University Press, Cambridge, U.K.

Barth J. R., C. Lin, Y. Ma, J. Seade, and F.M. Song, (2013), "Do Bank Regulation, Supervision and Monitoring Enhance or Impede Bank Efficiency?” Journal of Banking \& Finance, 37: 287992.

Beltratti, A., and R.M. Stulz, (2012), “The Credit Crisis Around the Globe: Why Did Some Banks Perform Better?" Journal of Financial Economics, 105: 1-17. 
Berger A., (1995), "The relationship between capital and earnings in banking," Journal of Money, Credit, and Banking, 27(2): 404-31.

Berger A., S.D. Bonime, D.M. Covitz, and D. Hancock, (2000), "Why Are Bank Profits So Persisent? The Roles of Product Market Competition, Informational Opacity, and Regional/Macroeconomic Shocks," Journal of Banking \& Finance, 24: 1203-35.

Berger, A. and C.H.S. Bouwman, (2013), "How Does Capital Affect Bank Performance During Financial Crises?" Journal of Financial Economics, 109: 146-76.

Bikker, J.A. and H. Hu, (2002). "Cyclical Patterns in Profits, Provisioning and Lending of Banks and Procyclicality of the New Basle Capital Requirements," BNL Quarterly Review, 221: 143175.

Borio, C., Gambacorta, L., Hofmann, B., (2017), “The influence of monetary policy on bank profitability," International Finance, March 2017, 20(1): 48-63.

Boudt, K., Carl, P., Peterson, B. G., (2012), “Asset Allocation with Conditional Value-at-Risk Budgets," Journal of Risk,15 (3): 39-68.

Bourke, P., (1989), "Concentration and Other Determinants of Bank Profitability in Europe, North America, and Australia," Journal of Banking and Finance, 13: 65-79.

Baudino, P., and H. Yun, (2017), "Resolution of Non-Performing Loans-Policy Options," FSI Insights on Policy Implementation, 3, BIS Financial Stability Institute.

Carbó Valverde, S., Rodríguez Fernández, F., (2007), “The determinants of bank margins in European banking," Journal of Banking and Finance, 31(7): 2043-2063.

Demirgüç-Kunt, A., Huizinga, H., (1999), "Determinants of Commercial Bank Interest Margins and Profitability: Some International Evidence,” World Bank Economic Review, 13(2): 379-408.

Demirgüç-Kunt, A., Huizinga, H., (2010), "Bank activity and funding strategies: The impact on risk and returns," Journal of Financial Economics, 98(3): 626-650.

Detragiache, E., Tressel, T., and Turk-Ariss, R., (2018), "Where Have All the Profits Gone? European Bank Profitability Over the Financial Cycle," IMF Working Paper 18/99.

Dietrich, A. and G. Wanzenried, (2011), "Determinants of Bank Profitability Before and During the Crisis: Evidence from Switzerland," Journal of International Financial Markets, Institutions \& Money, 21: 307-27.

European Central Bank (ECB), (2019), Financial Stability Review, May 2019.

Fernández, C., Steel, M. F. J., (2012), “On Bayesian Modeling of Fat Tails and Skewness,” Journal of the American Statistical Association, 93:441: 359-371, 
Freixas, X., B.M. Parigi, and J-C. Rochet, (2004), “The Lender of Last Resort: A Twenty-First Centurty Approach," Journal of the European Economic Association, 2(6): 1085-1115.

Erel, I., (2011), “The Effect of Bank Mergers on Loan Prices: Evidence from the U.S.” The Review of Financial Studies, 24(4): 1068-1101.

Gambacorta, L., M. Scatigna, and J. Yang, (2014), "Diversification and Bank Profitability: A Nonlinear Approach," Applied Economic Letters, 21(6): 438-41.

International Monetary Fund (IMF), (2014), "Risk Taking by Banks: The Role of Governance and Executive Pay," Global Financial Stability Report, October 2014, Chapter 3.

IMF, (2017), “Getting the Policy Mix Right," Global Financial Stability Report, April 2017, Chapter 1.

IMF, (2017), “Are Countries Losing Control of Domestic Financial Conditions?” Global Financial Stability Report, April 2017, Chapter 3.

IMF, (2017), "Financial Conditions and Growth at Risk," Global Financial Stability Report, October 2017, Chapter 3.

IMF, (2018), Euro Area Policies Financial Sector Assessment Program Technical Note-Systemic Risk Analysis. IMF Country Report No. 18/231.

Giot, P., Laurent, S. (2003), "Value-at-risk for long and short trading positions", Journal of Applied Economics, 18: 641-663.

Goddard, J., P. Molyneux, and J.O.S., Wilson, (2004), "Dynamics of Growth and Profitability in Banking”, Journal Money, Credit, and Banking, 36(6): 1069-90.

Hansen, B., (1994), “Autoregressive Conditional Density Estimation,” International Economic Review, 35(3): 705-30.

Hellmann, T.F., K.C., Murdock, and J.E. Stiglitz, (2000), "Liberalization, Moral Hazard in Banking, and Prudential Regulation: Are Capital Requirements Enough?" American Economic Review, 90(1): 147-65.

Huizinga, H., and L. Laeven, (2019), "The Procyclicality of Banking: Evidence from the Euro Area," ECB Working Paper, 2288.

Iannotta, G., G. Nocera, and A. Sironi, (2007), "Ownership Structure, Risk and Performance in the European Banking Industry," Journal of Banking and Finance, 31: 2127-49.

Koenker, R., Basset, G., (1978), "Regression Quantiles,” Econometrica, 46: 33-50.

Koenker, R., Ng, P., (2005), “Inequality Constrained Quantile Regression” Sankhyā: The Indian Journal of Statistics (2003-2007), 67(2): 418-440. 
Kok, C., C. More, and C. Pancaro, (2015), "Bank Profitability Challenges in Euro Area Banks: The Role of Cyclical and Structural Factors," ECB Financial Stability Review, May 2015: 13445.

Kok, C., C. More, and M. Petrescu, (2016), "Recent Trends in Euro Area Banks' Business Models and Implications for Banking Sector Stability," ECB Financial Stability Review, May 2016, Special Features: 1-13.

Kok, C., H. Mirza, C. More, and C. Pancaro, (2016), “Adapting Bank Business Models: Financial Stability Implications of Greater Reliance on Fee and Commission Income," ECB Financial Stability Review, November 2016, Special Features: 147-57.

Laeven, L. and R. Levine, (2009), “Bank Governance, Regulation, and Risk Taking,” Journal of Financial Economics, 93: 259-75.

Lambert, P., Laurent, S., (2002), "Modeling skewness dynamics in series of financial data using skewed location-scale distributions," Working Paper, Universite Catholique de Louvain and Universite de Liege.

Micco, A., U. Panizza, and M. Yanez, (2007), "Bank Ownership and Performance. Does Politics Matter?” Journal of Banking and Finance, 31: 219-41.

Mirzaei, A., T. Moore, and G. Liu, (2013), “Does Market Structure Matter on Banks' Profitability and Stability? Emerging vs. Advanced Economies," Journal of Banking \& Finance, 37: 2920-37.

Molyneux, P., Thornton, J., (1992), “Determinants of European bank profitability: A note," Journal of Banking and Finance, 16(6): 1173-1178.

Parente, P.M.D.C. and Santos Silva, J.M.C. 2016. "Quantile Regression with Clustered Data," Journal of Econometric Methods, forthcoming.

Roy, A. D. (1952), "Safety First and the Holding of Assets," Econometrica, 20(3): 431-449.

Shehzad, C. T., De Haan, J., Scholtens, B., (2013), “The relationship between size, growth and profitability of commercial banks," Applied economics, 45(13): 1751-1765.

Short, B.K., (1979), “The Relation Between Commercial Bank Profit Rates and Banking Concentration in Canada, Western Europe, and Japan," Journal of Banking and Finance, 3: 209-19.

Stiroh, K. J., (2004), “Diversification in Banking: Is Noninterest Income the Answer?" Journal of Money, Credit, and Banking, 36(5): 853-882.

Tan, G., (2019), “Beyond the Zero Lower Bound: Negative Policy Rates and Bank Lending,” DNB Working Paper 649. 
Tregenna, F., (2009), "The fat years: the structure and profitability of the US banking sector in the pre-crisis period," Cambridge Journal of Economics, 33(4): 609-632.

Valverde, S.C., and F.R., Fernandez, (2007), "The Determinants of Bank Margins in European Banking," Journal of Banking and Finance, 31: 2043-63.

Xu, T., Hu, K., and Das, U.S., (2019), “Bank Profitability and Financial Stability,” IMF Working Paper, 19/5. 